Supporting Information for:

\title{
Direct Conversion of Haloarenes to Phenols under Mild, Transition-Metal-Free Conditions
}

Patrick S. Fier* and Kevin M. Maloney* 


\section{General experimental details}

All reactions were assembled in screw-cap vials or round bottom flasks without precautions to avoid air or moisture. Acetohydroxamic acid and powdered $\mathrm{K}_{2} \mathrm{CO}_{3}$ were purchased from Sigma Aldrich and used as received. Unless otherwise noted, all substrates were purchased from commercial suppliers and used as received. Solvent grade DMSO was used in all reactions, and the water content was measured by KF to be $<1000 \mathrm{ppm}$. NMR chemical shifts are reported in ppm and referenced to residual solvent peaks. Coupling constants are reported in hertz.

\section{Procedure for the conversion of aryl halides to phenols}

To a screw-cap vial or round bottom flask is added acetohydroxamic acid (3.0 equiv), powdered $\mathrm{K}_{2} \mathrm{CO}_{3}$ (5.0 equiv), aryl halide substrate (1.0 equiv), and DMSO such that the substrate concentration was 0.3$0.6 \mathrm{M}$. In cases where the substrate is an oil, it is added by syringe or pipette after the DMSO is added. The vessel is sealed and heated at $80{ }^{\circ} \mathrm{C}$ for $2-18 \mathrm{~h}$, and monitored for conversion by HPLC or TLC. At the end of the reaction, the mixture is cooled to rt and carefully quenched with approximately 9 equiv. of $2 \mathrm{M} \mathrm{HCl}$ to a final $\mathrm{pH}$ of approximately $3-6$. The aqueous phase is extracted 2 times with EtOAc and the product is purified by silica gel chromatography. In some cases, the product precipitates directly during the addition of $\mathrm{HCl}$. In these cases, the solid is filtered and washed 3 times with water and dried under vacuum.

\section{Synthesis and Lossen rearrangement of $O$-(4-nitrophenyl)acetohydroxamate}

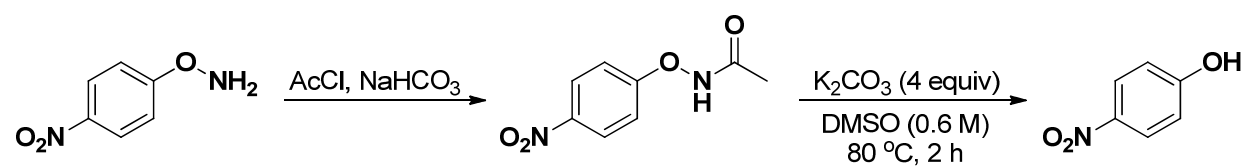

The procedure for preparing $O$-(4-nitrophenyl)acetohydroxamate was borrowed from Shen, Y.; Liu, G.; Zhou, Z.; Lu, X. Org. Lett. 2013, 15, 3366

O-(4-nitrophenyl)hydroxylamine ( $771 \mathrm{mg}, 5.00 \mathrm{mmol}, 1.00$ equiv) and $\mathrm{NaHCO}_{3}$ (504 mg, $6.00 \mathrm{mmol}, 1.20$ equiv) were added to a mixture of EtOAc $(5.6 \mathrm{~mL})$ and water $(2.8 \mathrm{~mL})$ and cooled to $5^{\circ} \mathrm{C}$. Acetyl chloride (356 $\mu \mathrm{L}, 5.00 \mathrm{mmol}, 1.00$ equiv) was added over 30 seconds. The reaction mixture was aged at $5{ }^{\circ} \mathrm{C}$ for $30 \mathrm{~min}$, then transferred to a separatory funnel with $20 \mathrm{~mL}$ of saturated aqueous $\mathrm{NaHCO}_{3}$ and $15 \mathrm{~mL}$ EtOAc. The organic layer was washed with $2 \times 10 \mathrm{~mL}$ saturated aqueous $\mathrm{NaHCO}_{3}$, dried over MgSO4 and concentrated to a white solid. The crude solid (94 LCAP purity by HPLC) was dissolved in $13 \mathrm{~mL}$ EtOAc at $35^{\circ} \mathrm{C}$ and $8 \mathrm{~mL}$ of hexanes was added dropwise. The slurry that formed was cooled to room temperature and the crystalline solid was isolated by filtration and washed with $2 \times 5 \mathrm{~mL}$ of 13:8 EtOAc:hexanes. The isolated yield of $O$-(4-nitrophenyl)acetohydroxamate was not determined.

The ${ }^{1} \mathrm{H}$ NMR spectrum matched that previously reported for this compound.

$\mathrm{O}$-(4-nitrophenyl)acetohydroxamate $\left(98 \mathrm{mg}, 0.50 \mathrm{mmol}, 1.0\right.$ equiv) and powdered $\mathrm{K}_{2} \mathrm{CO}_{3}(276 \mathrm{mg}, 2.00$ mmol, 4.00 equiv) were added to a vial. DMSO $(0.8 \mathrm{~mL})$ was added and the mixture was heated at $80^{\circ} \mathrm{C}$ and monitored by HPLC. After 40 minutes, complete conversion to 4-nitrophenol was observed. 


\section{Ethyl 4-hydroxybenzoate (2a)}

performed with $336 \mathrm{mg}(2.00 \mathrm{mmol})$ of ethyl 4 -fluorobenzoate in DMSO $(0.6 \mathrm{M})$ at $80{ }^{\circ} \mathrm{C}$
for $16 \mathrm{~h}$. The product was purified on silica gel with a gradient of EtOAc in hexanes, and obtained as a white solid in $87 \%$ yield $(290 \mathrm{mg})$.

${ }^{1} \mathrm{H}$ NMR $(400 \mathrm{MHz}$, Chloroform-d) $\delta 8.00-7.93(\mathrm{~m}, 2 \mathrm{H}), 6.90-6.82(\mathrm{~m}, 2 \mathrm{H}), 5.65(\mathrm{~s}, 1 \mathrm{H}), 4.35(\mathrm{q}, \mathrm{J}=$ $7.1 \mathrm{~Hz}, 2 \mathrm{H}), 1.38(\mathrm{t}, \mathrm{J}=7.1 \mathrm{~Hz}, 3 \mathrm{H})$.

${ }^{13} \mathrm{C}$ NMR $(101 \mathrm{MHz}$, Chloroform-d) $\delta 167.22,160.41,131.90,122.33,115.26,61.05,14.28$.

\section{4'-hydroxyacetophenone (2b)}

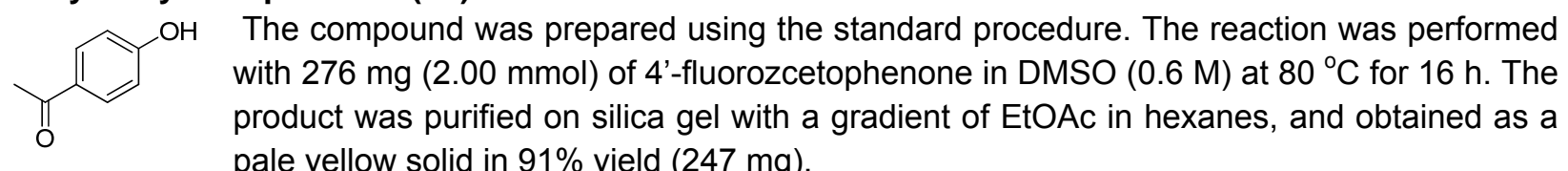
pale yellow solid in $91 \%$ yield $(247 \mathrm{mg})$.

${ }^{1} \mathrm{H}$ NMR (400 MHz, Chloroform-d) $\delta 7.96-7.87(\mathrm{~m}, 2 \mathrm{H}), 6.94-6.89(\mathrm{~m}, 2 \mathrm{H}), 6.43(\mathrm{~s}, 1 \mathrm{H}), 2.58(\mathrm{~s}, 3 \mathrm{H})$.

${ }^{13} \mathrm{C}$ NMR (101 MHz, Chloroform-d) $\delta$ 198.99, 161.60, 131.27, 129.31, 115.58, 26.27.

HRMS, calculated (M-H): 135.0446

HRMS, measured (M-H): 135.0439

\section{4-hydroxybenzonitrile (2c)}

The compound was prepared using the standard procedure. The reaction was
performed with $242 \mathrm{mg}(2.00 \mathrm{mmol})$ of 4 -fluorobenzonitrile in DMSO $(0.6 \mathrm{M})$ at $80{ }^{\circ} \mathrm{C}$ for
$16 \mathrm{~h}$. The product was purified on silica gel with a gradient of EtOAc in hexanes, and obtained as a white solid in $93 \%$ yield $(222 \mathrm{mg})$.

${ }^{1} \mathrm{H}$ NMR (400 MHz, Chloroform-d) $\delta 7.61-7.52(\mathrm{~m}, 2 \mathrm{H}), 6.96-6.87(\mathrm{~m}, 2 \mathrm{H}), 5.86(\mathrm{~s}, 1 \mathrm{H})$.

${ }^{13} \mathrm{C}$ NMR $(101 \mathrm{MHz}$, Chloroform-d) $\delta 160.23,134.31,119.22,116.45,102.88$.

HRMS, calculated (M-H): 118.0293

HRMS, measured (M-H): 118.0296

\section{4-nitrophenol (2d)}

$\mathrm{OH}$ The compound was prepared using the standard procedure. The reaction was performed with $315 \mathrm{mg}(2.00 \mathrm{mmol})$ of 1-chloro-4-nitrobenzene in DMSO $(0.6 \mathrm{M})$ at 80 ${ }^{\circ} \mathrm{C}$ for $18 \mathrm{~h}$. The product was purified on silica gel with a gradient of EtOAc in hexanes, and obtained as a yellow solid in $92 \%$ yield $(255 \mathrm{mg})$.

${ }^{1} \mathrm{H}$ NMR $(500 \mathrm{MHz}$, Chloroform-d) $\delta 8.23-8.13(\mathrm{~m}, 2 \mathrm{H}), 6.97-6.88(\mathrm{~m}, 2 \mathrm{H}), 5.85(\mathrm{~s}, 1 \mathrm{H})$.

${ }^{13} \mathrm{C}$ NMR $(101 \mathrm{MHz}$, Chloroform-d) $\delta 161.31,126.30,115.71$. The resonance for the carbon atom attached to the nitro group was not observed in the ${ }^{13} \mathrm{C}$ NMR spectrum

HRMS, calculated (M-H): 138.0191

HRMS, measured (M-H): 138.0214

\section{4-hydroxyphenyl methyl sulfone (2e)}

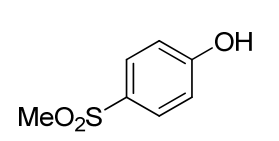

The compound was prepared using the standard procedure. The reaction was performed with $348 \mathrm{mg}(2.00 \mathrm{mmol})$ of 1-fluoro-4-(methylsulfonyl)benzene in DMSO $(0.6 \mathrm{M})$ at $80{ }^{\circ} \mathrm{C}$ for $18 \mathrm{~h}$. The product was purified on silica gel with a gradient of EtOAc in hexanes, and obtained as a colorless oil which solidified on standing in $88 \%$ yield $(303 \mathrm{mg})$.

${ }^{1} \mathrm{H}$ NMR (400 MHz, Chloroform-d) $\delta 7.88-7.79(\mathrm{~m}, 2 \mathrm{H}), 7.02-6.93(\mathrm{~m}, 2 \mathrm{H}), 5.66(\mathrm{~s}, 1 \mathrm{H}), 3.04(\mathrm{~s}, 3 \mathrm{H})$.

${ }^{13} \mathrm{C}$ NMR (101 MHz, Chloroform- $d$ ) $\delta 161.27,130.87,129.59,116.24,44.88$.

HRMS, calculated (M-H): 171.0116. 
HRMS, measured (M-H): 171.0124

\section{2-hydroxyphenyl methyl sulfone (2f)}

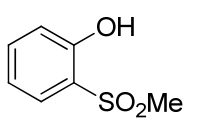

The compound was prepared using the standard procedure. The reaction was performed with $348 \mathrm{mg}(2.00 \mathrm{mmol})$ of 1-fluoro-2-(methylsulfonyl)benzene in DMSO (0.6 $\mathrm{M})$ at $80{ }^{\circ} \mathrm{C}$ for $3 \mathrm{~h}$. The product was purified on silica gel with a gradient of EtOAc in hexanes, and obtained as a white solid in $87 \%$ yield $(301 \mathrm{mg})$.

${ }^{1} \mathrm{H}$ NMR $(400 \mathrm{MHz}$, Chloroform-d) $\delta 8.84(\mathrm{~s}, 1 \mathrm{H}), 7.69(\mathrm{dd}, \mathrm{J}=8.2,1.7 \mathrm{~Hz}, 1 \mathrm{H}), 7.54$ (ddd, $\mathrm{J}=8.4,7.4$, $1.7 \mathrm{~Hz}, 1 \mathrm{H}), 7.13-6.98(\mathrm{~m}, 2 \mathrm{H}), 3.13(\mathrm{~s}, 3 \mathrm{H})$.

${ }^{13} \mathrm{C}$ NMR (101 MHz, Chloroform-d) $\delta 155.78,136.49,128.61,122.73,120.75,119.07,44.93$.

HRMS, calculated (M-H): 171.0116

HRMS, measured (M-H): 171.0135

\section{N,N-diethyl-4-hydroxybenzenesulfonamide (2g)}

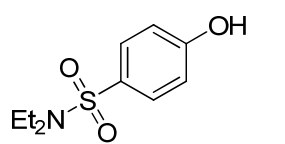

The compound was prepared using the standard procedure. The reaction was performed with $463 \mathrm{mg}(2.00 \mathrm{mmol})$ of $\mathrm{N}, \mathrm{N}$-diethyl-4-fluorobenzenesulfonamide in DMSO $(0.6 \mathrm{M})$ at $80{ }^{\circ} \mathrm{C}$ for $18 \mathrm{~h}$. The product was purified on silica gel with a gradient of EtOAc in hexanes, and obtained as a colorless oil in $89 \%$ yield $(408 \mathrm{mg})$.

${ }^{1} \mathrm{H}$ NMR $(400 \mathrm{MHz}$, Chloroform-d) $\delta 7.72-7.64(\mathrm{~m}, 2 \mathrm{H}), 6.95-6.87(\mathrm{~m}, 2 \mathrm{H}), 6.03(\mathrm{~s}, 1 \mathrm{H}), 3.21(\mathrm{q}, \mathrm{J}=$ $7.1 \mathrm{~Hz}, 4 \mathrm{H}), 1.12(\mathrm{t}, \mathrm{J}=7.1 \mathrm{~Hz}, 6 \mathrm{H})$.

${ }^{13} \mathrm{C}$ NMR $(101 \mathrm{MHz}$, Chloroform-d) $\delta$ 159.94, 130.92, 129.16, 115.86, 41.98, 14.01.

HRMS, calculated $(\mathrm{M}+\mathrm{H}): 230.0851$

HRMS, measured $(\mathrm{M}+\mathrm{H}): 230.0864$

\section{2-bromo-4-(trifluoromethyl)phenol (2h)}

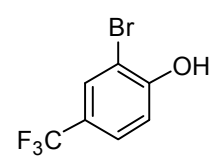

The compound was prepared using the standard procedure. The reaction was performed with $486 \mathrm{mg}$ (2.00 mmol) of 2-bromo-1-fluoro-4-(trifluoromethyl)benzene in DMSO (0.3 M) at $80{ }^{\circ} \mathrm{C}$ for $18 \mathrm{~h}$. The product was purified on silica gel with a gradient of EtOAc in hexanes, and obtained as a colorless oil in $86 \%$ yield $(415 \mathrm{mg})$.

${ }^{1} \mathrm{H}$ NMR (400 MHz, Chloroform-d) $\delta 7.75$ (dd, $\left.J=2.2,0.8 \mathrm{~Hz}, 1 \mathrm{H}\right), 7.50$ (ddd, $J=8.5,2.2,0.8 \mathrm{~Hz}, 1 \mathrm{H}$ ), 7.10 (dq, $J=8.6,0.9 \mathrm{~Hz}, 1 \mathrm{H}), 5.81(\mathrm{~s}, 1 \mathrm{H})$.

${ }^{13} \mathrm{C}$ NMR (101 MHz, Chloroform-d) $\delta 155.00,129.48(q, J=3.9 \mathrm{~Hz}), 126.54(q, J=3.6 \mathrm{~Hz}), 121.99$, 116.24, 110.14. The ${ }^{13} \mathrm{C}$ resonances of the $\mathrm{CF}_{3}$ group were not well resolved in the ${ }^{13} \mathrm{C}$ NMR spectrum.

\section{3-nitro-4-hydroxybenzoic acid (2i)}

The compound was prepared using the standard procedure. The reaction was
$80^{\circ} \mathrm{C}$ for $1 \mathrm{~h}$. The product was purified on silica gel with a gradient of EtOAc in hexanes,
and obtained as a pale yellow solid in $93 \%$ yield $(342 \mathrm{mg})$. ${ }^{1} \mathrm{H}$ NMR $\left(400 \mathrm{MHz}, \mathrm{DMSO}_{6}\right) \delta 13.16(\mathrm{~s}, 1 \mathrm{H}), 11.90(\mathrm{~s}, 1 \mathrm{H}), 8.36$ (d, $\left.\mathrm{J}=2.2 \mathrm{~Hz}, 1 \mathrm{H}\right), 8.05$ (dd, $\mathrm{J}=8.7$, $2.2 \mathrm{~Hz}, 1 \mathrm{H}), 7.21(\mathrm{~d}, \mathrm{~J}=8.7 \mathrm{~Hz}, 1 \mathrm{H})$.

${ }^{13} \mathrm{C}$ NMR $\left(101 \mathrm{MHz}\right.$, DMSO- $\left.d_{6}\right) \delta 166.04,155.97,137.10,135.90,127.25,122.10,119.64$.

HRMS, calculated (M-H): 182.0090

HRMS, measured (M-H): 182.0097

\section{2-hydroxynicotinamide (2j)}

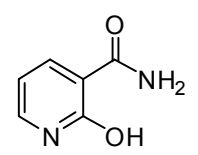

The compound was prepared using the standard procedure. The reaction was performed with $783 \mathrm{mg}(5.00 \mathrm{mmol})$ of 2-chloronicotinamide in DMSO $(0.4 \mathrm{M})$ at $80{ }^{\circ} \mathrm{C}$ for $12 \mathrm{~h}$. The product was isolated directly from the reaction mixture upon the addition of 9 equiv of $2 \mathrm{M}$ 
$\mathrm{HCl}$ over approximately 5 minutes while cooling at $5{ }^{\circ} \mathrm{C}$. The obtained solid was washed 2 times with water and dried to afford the compound as a white solid in $70 \%$ yield $(483 \mathrm{mg})$.

${ }^{1} \mathrm{H}$ NMR $\left(400 \mathrm{MHz}\right.$, DMSO- $\left.d_{6}\right) \delta 12.43(\mathrm{~s}, 1 \mathrm{H}), 9.08(\mathrm{~s}, 1 \mathrm{H}), 8.32(\mathrm{dd}, \mathrm{J}=7.1,2.3 \mathrm{~Hz}, 1 \mathrm{H}), 7.70(\mathrm{dd}, \mathrm{J}=$ 6.3, $2.3 \mathrm{~Hz}, 1 \mathrm{H}), 7.56(\mathrm{~s}, 1 \mathrm{H}), 6.44$ (dd, $J=7.1,6.3 \mathrm{~Hz}, 1 \mathrm{H})$.

${ }^{13} \mathrm{C}$ NMR $\left(101 \mathrm{MHz}\right.$, DMSO- $\left.d_{6}\right) \delta 165.08,162.73,144.70,140.08,121.27,106.47$.

HRMS, calculated (M-H): 137.0351

HRMS, measured (M-H): 137.0361

\section{2-hydroxyquinoline (2k)}

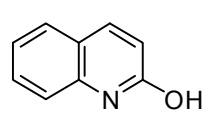

The compound was prepared using the standard procedure. The reaction was performed with $818 \mathrm{mg}(5.00 \mathrm{mmol})$ of 2-chloroquinoline in DMSO $(0.4 \mathrm{M})$ at $80^{\circ} \mathrm{C}$ for $12 \mathrm{~h}$. The product was isolated directly from the reaction mixture upon the addition of 9 equiv of $2 \mathrm{M}$ $\mathrm{HCl}$ over approximately 5 minutes while cooling at $5{ }^{\circ} \mathrm{C}$. The obtained solid was washed 2 times with water and dried to afford the compound as a white solid in $85 \%$ yield $(616 \mathrm{mg})$.

${ }^{1} \mathrm{H}$ NMR $\left(400 \mathrm{MHz}, \mathrm{DMSO}-d_{6}\right) \delta 11.74(\mathrm{~s}, 1 \mathrm{H}), 7.89(\mathrm{dd}, J=9.6,0.6 \mathrm{~Hz}, 1 \mathrm{H}), 7.65(\mathrm{dd}, J=7.8,1.4 \mathrm{~Hz}$, $1 \mathrm{H}$ ), 7.49 (ddd, $J=8.5,7.2,1.5 \mathrm{~Hz}, 1 \mathrm{H}$ ), 7.30 (ddt, $J=8.3,1.2,0.6 \mathrm{~Hz}, 1 \mathrm{H}$ ), 7.16 (ddd, $J=8.1,7.2,1.1$ $\mathrm{Hz}, 1 \mathrm{H}), 6.49(\mathrm{~d}, \mathrm{~J}=9.5 \mathrm{~Hz}, 1 \mathrm{H})$.

${ }^{13} \mathrm{C}$ NMR $\left(101 \mathrm{MHz}\right.$, DMSO- $\left.d_{6}\right) \delta 162.36,140.67,139.32,130.79,128.32,122.36,122.18,119.54$, 115.56 .

HRMS, calculated $(\mathrm{M}+\mathrm{H}): 146.0606$

HRMS, measured $(M+H): 146.0616$

\section{2-(trifluoromethyl)pyridin-5-ol (2l)}

$\mathrm{OH}$ The compound was prepared using the standard procedure. The reaction was performed with $1.00 \mathrm{~g}(4.42 \mathrm{mmol})$ of 5-bromo-2-(trifluoromethyl)pyridine in DMSO $(0.4 \mathrm{M})$ at $80{ }^{\circ} \mathrm{C}$ for $18 \mathrm{~h}$. The product was purified on silica gel with a gradient of EtOAc in hexanes, and obtained as a white solid in $89 \%$ yield $(640 \mathrm{mg})$.

${ }^{1} \mathrm{H}$ NMR $\left(400 \mathrm{MHz}, \mathrm{DMSO}-\mathrm{d}_{6}\right) \delta 10.86(\mathrm{~s}, 1 \mathrm{H}), 8.26(\mathrm{~d}, \mathrm{~J}=2.8 \mathrm{~Hz}, 1 \mathrm{H}), 7.70(\mathrm{dd}, \mathrm{J}=8.6,0.6 \mathrm{~Hz}, 1 \mathrm{H})$, 7.34 (ddt, $J=8.6,2.8,0.7 \mathrm{~Hz}, 1 \mathrm{H}$ ).

${ }^{13} \mathrm{C}$ NMR $\left(101 \mathrm{MHz}\right.$, DMSO- $\left.d_{6}\right) \delta 156.84,139.00,137.53$ (q, $\left.\mathrm{J}=33.9 \mathrm{~Hz}\right), 123.16,122.57$ (d, $\mathrm{J}=272.4$ $\mathrm{Hz}), 122.39$ (q, $J=2.6 \mathrm{~Hz}$ ).

HRMS, calculated (M-H): 162.0167

HRMS, measured $(M-H): 162.0182$

\section{4-phenylpyrimidin-2-ol (2m)}

The compound was prepared using the standard procedure. The reaction was performed
with $850 \mathrm{mg}(4.46 \mathrm{mmol})$ of 4 -chloro-2-phenylpyrimidine in DMSO $(0.4 \mathrm{M})$ at $80^{\circ} \mathrm{C}$ for $12 \mathrm{~h}$. $2 \mathrm{M} \mathrm{HCl}$ and cooling to $5^{\circ} \mathrm{C}$. The obtained solid was washed 2 times with water and dried to afford the compound as a white solid in $87 \%$ yield $(670 \mathrm{mg})$.

${ }^{1} \mathrm{H}$ NMR $\left(400 \mathrm{MHz}\right.$, DMSO- $\left.d_{6}\right) \delta 11.92(\mathrm{~s}, 1 \mathrm{H}), 8.13-8.07(\mathrm{~m}, 2 \mathrm{H}), 8.05(\mathrm{~d}, \mathrm{~J}=6.5 \mathrm{~Hz}, 1 \mathrm{H}), 7.62-7.49$ $(\mathrm{m}, 3 \mathrm{H}), 6.99(\mathrm{~d}, \mathrm{~J}=6.5 \mathrm{~Hz}, 1 \mathrm{H})$.

${ }^{13} \mathrm{C}$ NMR (101 MHz, DMSO- $\left.d_{6}\right) \delta 157.16,136.47,132.20,129.28,128.00,100.75$. Two carbon resonances of the pyrimidine ring were not observed in the ${ }^{13} \mathrm{C}$ NMR spectrum

HRMS, calculated $(\mathrm{M}+\mathrm{H}): 173.0715$

HRMS, measured $(\mathrm{M}+\mathrm{H}): 173.0722$ 


\section{5-phenylpyrazin-2-ol (2n)}<smiles>Oc1cnc(-c2ccccc2)cn1</smiles>

The compound was prepared using the standard procedure. The reaction was performed with $953 \mathrm{mg}(5.00 \mathrm{mmol})$ of 2-chloro-5-phenylpyrazine in DMSO $(0.4 \mathrm{M})$ at $80{ }^{\circ} \mathrm{C}$ for $12 \mathrm{~h}$.

The product was isolated directly from the reaction mixture upon the addition of 9 equiv of $2 \mathrm{M} \mathrm{HCl}$ over approximately 5 minutes while cooling at $5{ }^{\circ} \mathrm{C}$. The obtained solid was washed 2 times with water and dried to afford the compound as a white solid in $91 \%$ yield $(782 \mathrm{mg})$.

${ }^{1} \mathrm{H}$ NMR $\left(400 \mathrm{MHz}\right.$, DMSO- $\left.d_{6}\right) \delta 12.49(\mathrm{br}, 1 \mathrm{H}), 8.12(\mathrm{~d}, \mathrm{~J}=1.4 \mathrm{~Hz}, 1 \mathrm{H}), 8.06(\mathrm{~d}, \mathrm{~J}=1.4 \mathrm{~Hz}, 1 \mathrm{H}), 7.91-$ $7.83(\mathrm{~m}, 2 \mathrm{H}), 7.41(\mathrm{dd}, \mathrm{J}=8.4,6.9 \mathrm{~Hz}, 2 \mathrm{H}), 7.35-7.26(\mathrm{~m}, 1 \mathrm{H})$.

${ }^{13} \mathrm{C}$ NMR $\left(101 \mathrm{MHz}\right.$, DMSO- $\left.d_{6}\right) \delta 156.34,146.65,136.21,133.58,129.14,127.93,125.95,125.01$.

HRMS, calculated $(\mathrm{M}+\mathrm{H}): 173.0715$

HRMS, measured $(\mathrm{M}+\mathrm{H}): 173.0731$

\section{6-phenylpyridazin-3-ol (20)}

The compound was prepared using the standard procedure. The reaction was performed with $953 \mathrm{mg}(5.00 \mathrm{mmol})$ of 3-chloro-6-phenylpyridazine in DMSO $(0.4 \mathrm{M})$ at $80^{\circ} \mathrm{C}$ for $12 \mathrm{~h}$.

${ }^{N}{ }_{\mathrm{OH}}$ The product was isolated directly from the reaction mixture upon the addition of 9 equiv of $2 \mathrm{M} \mathrm{HCl}$ over approximately 5 minutes while cooling at $5{ }^{\circ} \mathrm{C}$. The obtained solid was washed 2 times with water and dried to afford the compound as a white solid in $95 \%$ yield $(818 \mathrm{mg})$.

${ }^{1} \mathrm{H}$ NMR $\left(400 \mathrm{MHz}, \mathrm{DMSO}-d_{6}\right) \delta 13.21(\mathrm{~s}, 1 \mathrm{H}), 8.04(\mathrm{~d}, \mathrm{~J}=9.9 \mathrm{~Hz}, 1 \mathrm{H}), 7.90-7.83(\mathrm{~m}, 2 \mathrm{H}), 7.52-7.40$ $(\mathrm{m}, 3 \mathrm{H}), 6.99(\mathrm{~d}, \mathrm{~J}=9.9 \mathrm{~Hz}, 1 \mathrm{H})$.

${ }^{13} \mathrm{C}$ NMR $\left(101 \mathrm{MHz}\right.$, DMSO- $\left.d_{6}\right) \delta 160.68,144.22,135.06,131.93,130.61,129.64,129.37,126.08$.

HRMS, calculated $(\mathrm{M}+\mathrm{H}): 173.0715$

HRMS, measured $(\mathrm{M}+\mathrm{H})$ : 173.0726

\section{Ethyl 4'-acetamido-5-amino-4-chloro-5'-hydroxy-2'-nitrobiphenyl-2-carboxylate (20)}<smiles>CCOC(=O)c1cc(Cl)c(N)cc1-c1cc(O)c(NC(C)=O)cc1[N+](=O)[O-]</smiles>

The compound was prepared using the standard procedure. The reaction was performed with $119 \mathrm{mg}(0.300 \mathrm{mmol})$ of 10 in DMSO $(0.6 \mathrm{M})$ at $80{ }^{\circ} \mathrm{C}$ for $2 \mathrm{~h}$. The product was isolated directly from the reaction mixture upon the addition of 9 equiv of $2 \mathrm{M} \mathrm{HCl}$ over approximately 5 minutes. The obtained solid was washed 2 times with water and dried to afford the compound as a tan solid in $85 \%$ yield (101 mg).

${ }^{1} \mathrm{H}$ NMR (400 MHz, DMSO-d $\left.)_{6}\right) \delta 11.41(\mathrm{~s}, 1 \mathrm{H}), 9.53(\mathrm{~s}, 1 \mathrm{H}), 8.86(\mathrm{~s}, 1 \mathrm{H}), 7.79(\mathrm{~s}, 1 \mathrm{H}), 6.62(\mathrm{~s}, 1 \mathrm{H}), 6.54$ (s, 1H), $6.30(\mathrm{~s}, 2 \mathrm{H}), 3.92(\mathrm{q}, \mathrm{J}=7.1 \mathrm{~Hz}, 2 \mathrm{H}), 2.16(\mathrm{~s}, 3 \mathrm{H}), 0.98(\mathrm{t}, \mathrm{J}=7.1 \mathrm{~Hz}, 3 \mathrm{H})$.

${ }^{13} \mathrm{C}$ NMR $\left(101 \mathrm{MHz}\right.$, DMSO- $\left.d_{6}\right) \delta 169.79,164.88,152.24,148.80,141.33,138.99,134.52,131.96$, $126.25,117.92,116.69,115.97,115.64,115.42,60.32,24.30,14.18$.

HRMS, calculated $(\mathrm{M}+\mathrm{H}): 394.0806$

HRMS, measured $(\mathrm{M}+\mathrm{H}): 394.0817$

\section{(2S,4R)-1-tert-butyl-2-methyl-4-((3-hydroxy-7-methoxyquinoxalin-2-yl)oxy)pyrrolidine-1,2-} dicarboxylate $(2 p)$

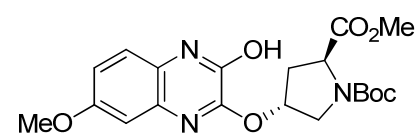

The compound was prepared using the standard procedure. The reaction was performed with $876 \mathrm{mg}(2.00 \mathrm{mmol})$ of $1 \mathrm{p}$ in DMSO $(0.6 \mathrm{M})$ at $40^{\circ} \mathrm{C}$ for $2 \mathrm{~h}$. The product was isolated directly from the reaction mixture upon the addition of 9 equiv of $2 \mathrm{M} \mathrm{HCl}$ over approximately 5 minutes. The obtained solid was washed 2 times with 5:1 water:acetone and dried to afford the compound as a white solid in $93 \%$ yield $(784 \mathrm{mg})$.

${ }^{1} \mathrm{H}$ NMR $\left(400 \mathrm{MHz}\right.$, DMSO- $\left.d_{6}\right) \delta 12.30(\mathrm{~s}, 1 \mathrm{H}), 7.16(\mathrm{~d}, \mathrm{~J}=8.8 \mathrm{~Hz}, 1 \mathrm{H}), 7.04(\mathrm{~d}, \mathrm{~J}=2.7 \mathrm{~Hz}, 1 \mathrm{H}), 7.00$ (dd, $J=8.8,2.8 \mathrm{~Hz}, 1 \mathrm{H}), 5.56(\mathrm{~m}, 1 \mathrm{H}), 4.33(\mathrm{q}, \mathrm{J}=7.6 \mathrm{~Hz}, 1 \mathrm{H}), 3.79(\mathrm{~m}, 4 \mathrm{H}), 3.69$ (two rotameric peaks for 
$\mathrm{CO}_{2}$ Me group, 3H), $3.66-3.56(\mathrm{~m}, 1 \mathrm{H}), 2.65-2.53(\mathrm{~m}, 1 \mathrm{H}), 2.32(\mathrm{~m}, 1 \mathrm{H}), 1.38$ (two rotameric peaks for Boc group, $9 \mathrm{H}$ ).

The ${ }^{13} \mathrm{C}$ NMR spectrum is complicated due to the presence of two rotamers about the N-Boc group

${ }^{13} \mathrm{C}$ NMR $\left(101 \mathrm{MHz}\right.$, DMSO-d $\left.\mathrm{d}_{6}\right) \delta 173.21,172.79,155.98,154.69,153.91,153.24,150.28,131.18$, $124.80,116.22$, 116.04, 109.17, 80.06, 79.97, 75.33, 74.62, 57.99, 57.78, 55.96, 52.51, 52.44, 52.33, $52.13,36.01,35.23,28.47,28.29$.

HRMS, calculated $(2 \mathrm{M}+\mathrm{H}): 839.3464$

HRMS, measured $(2 \mathrm{M}+\mathrm{H}): 839.3470$ 
$400 \mathrm{MHz}$, Chloroform-d<smiles>CCOC(=O)c1ccc(O)cc1</smiles>

$2 a$
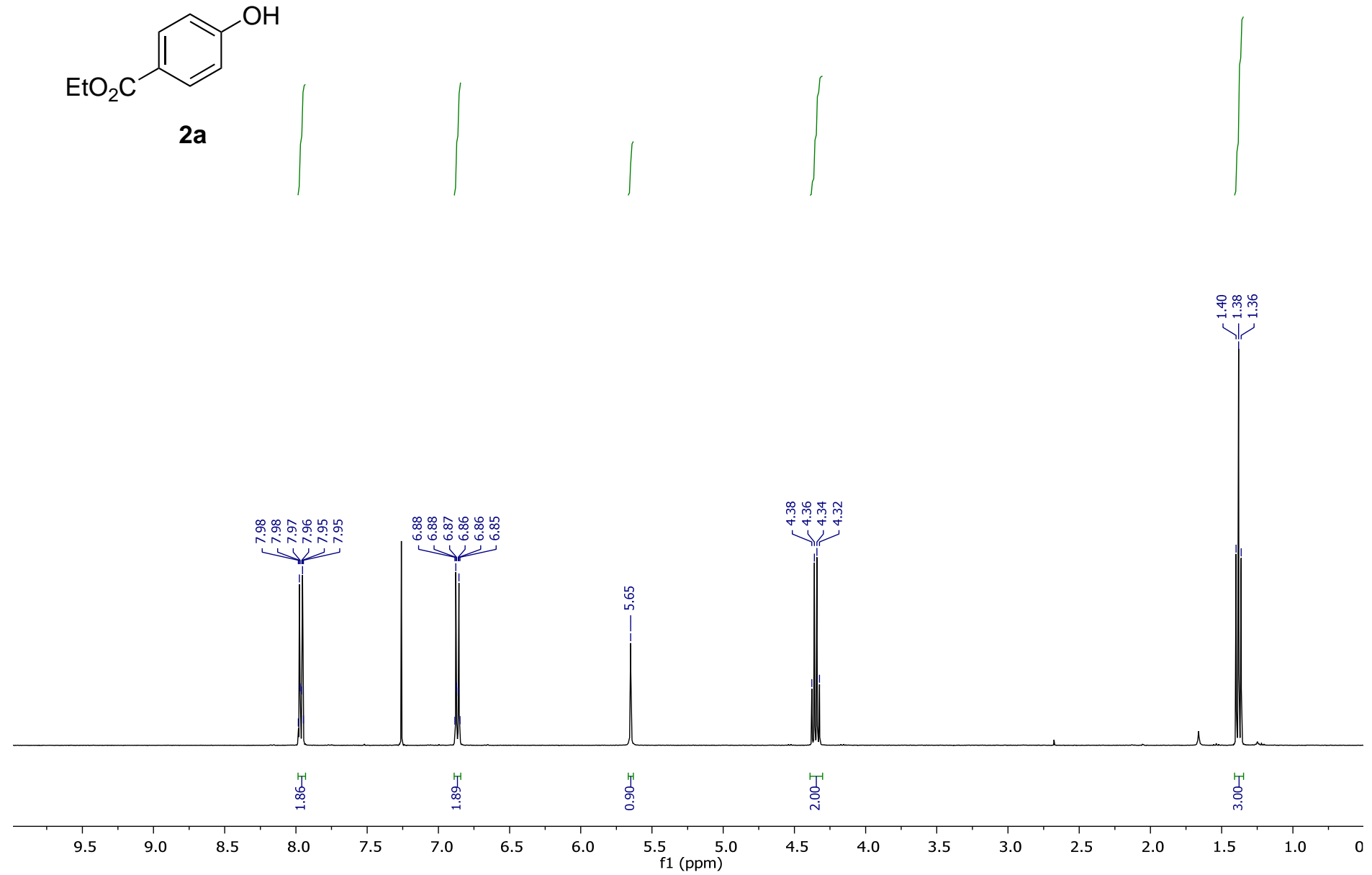

$101 \mathrm{MHz}$, Chloroform-d

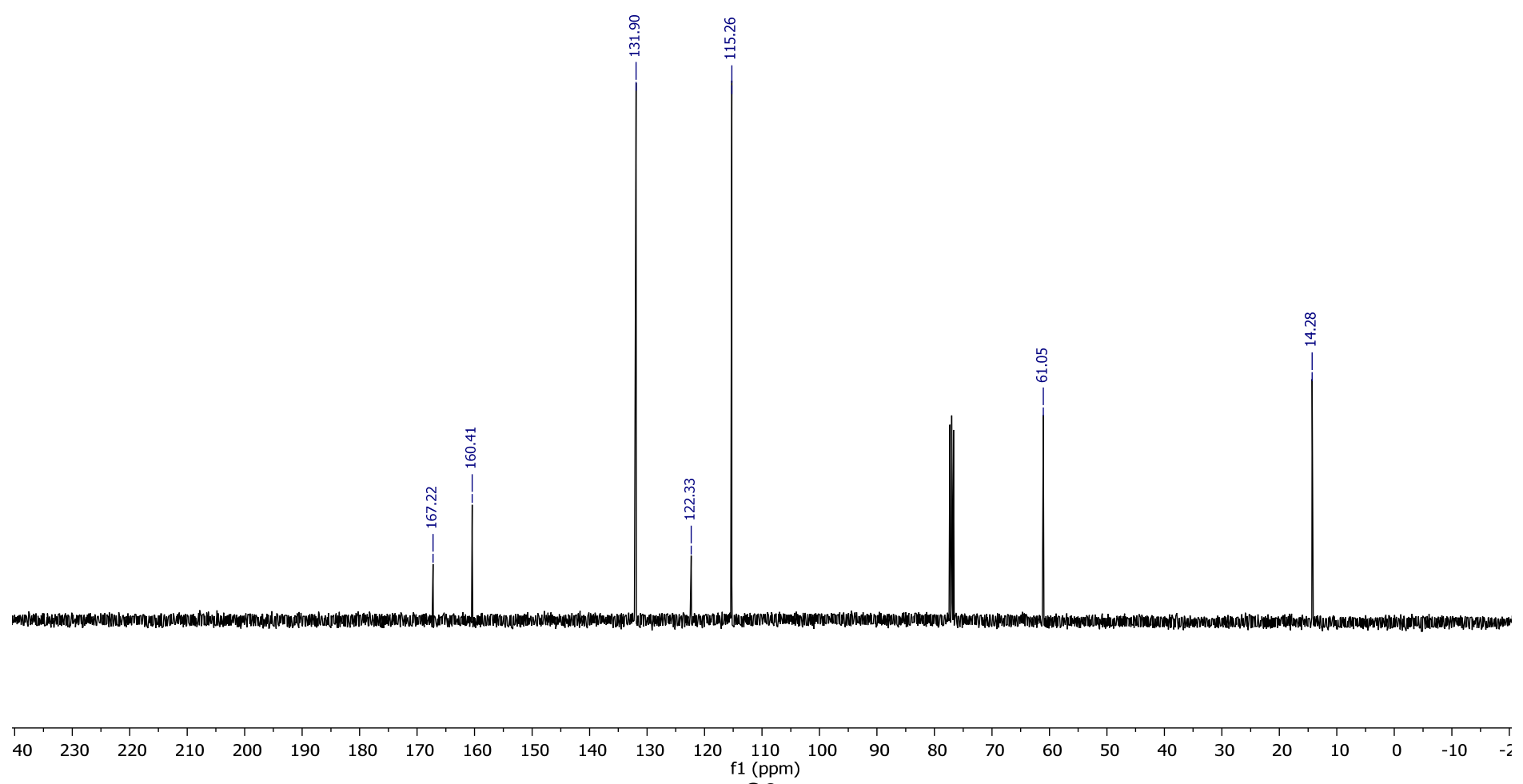


$400 \mathrm{MHz}$, Chloroform-d<smiles>CC(=O)c1ccc(O)cc1</smiles>
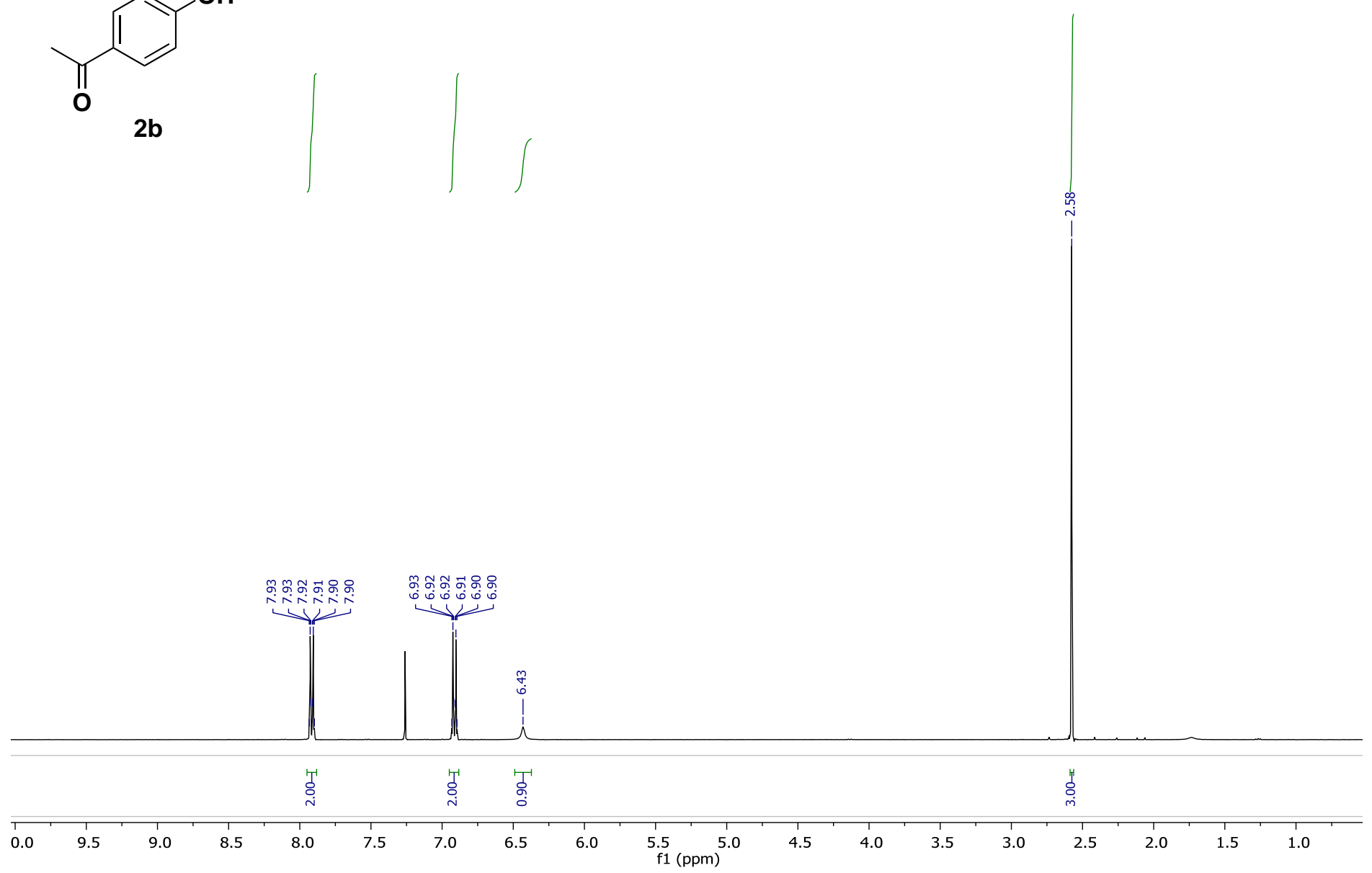

$101 \mathrm{MHz}$, Chloroform-d
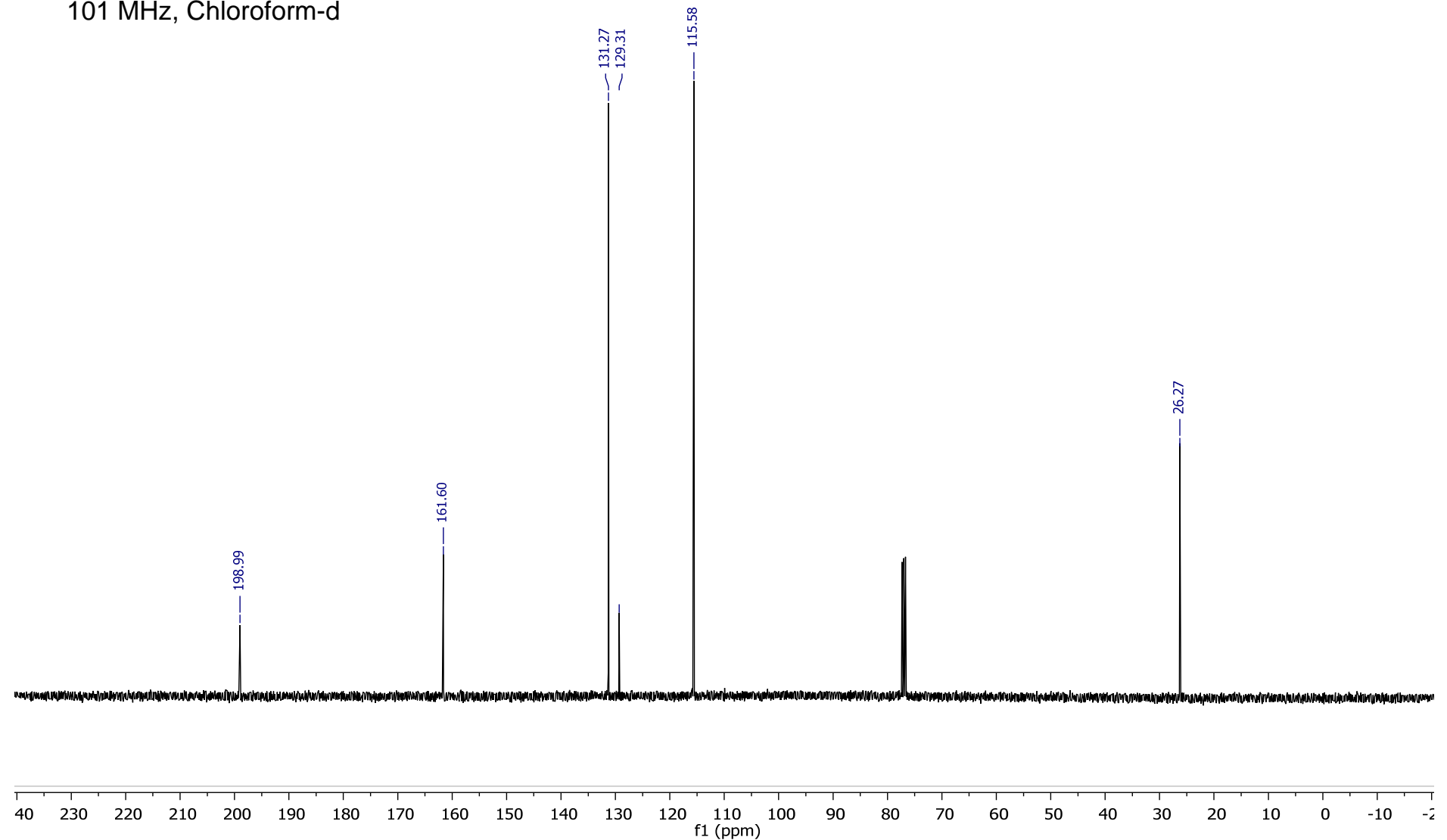
$400 \mathrm{MHz}$, Chloroform-d<smiles>N#Cc1ccc(O)cc1</smiles>
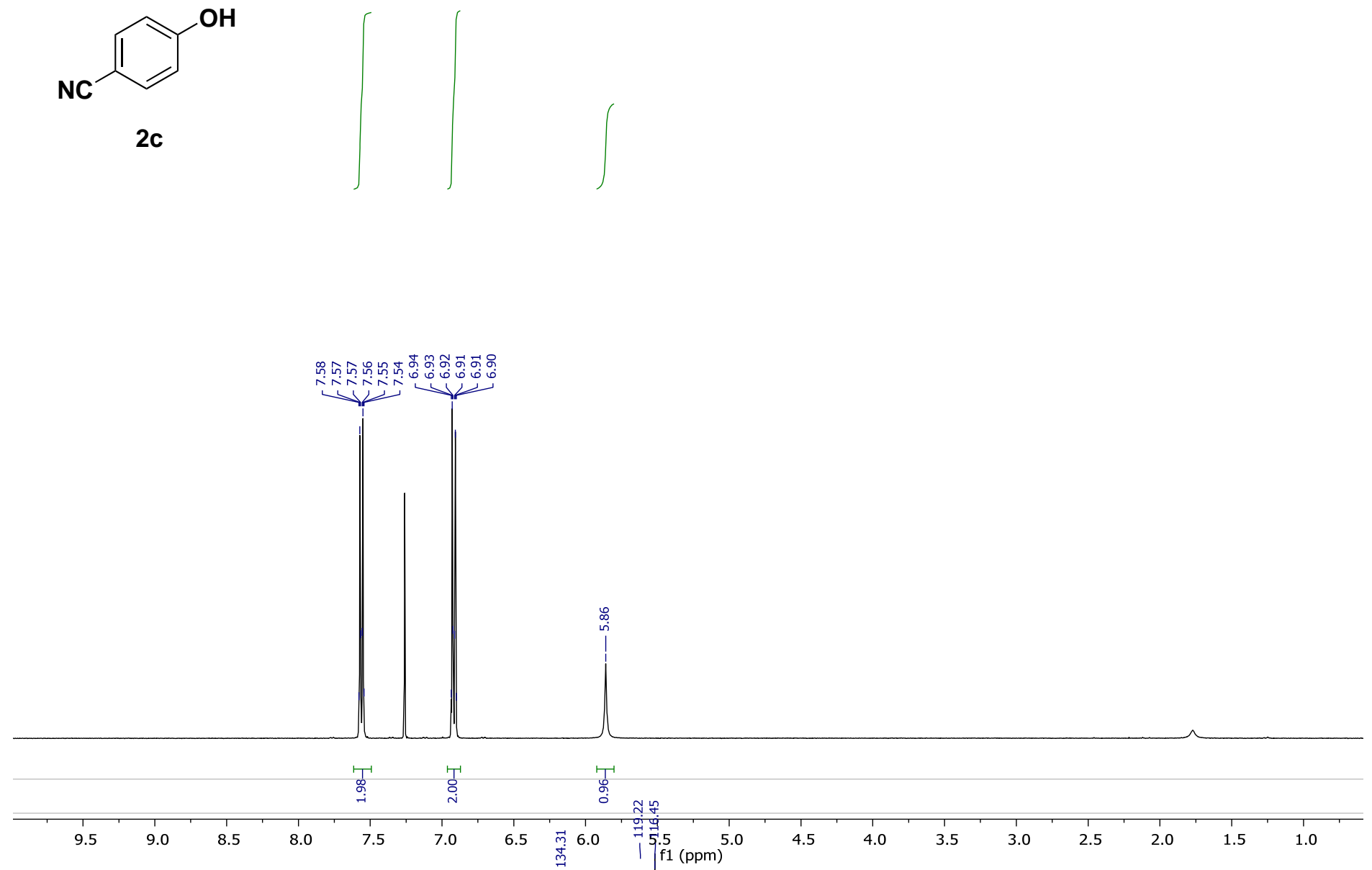

$101 \mathrm{MHz}$, Chloroform-d 
$500 \mathrm{MHz}$, Chloroform-d
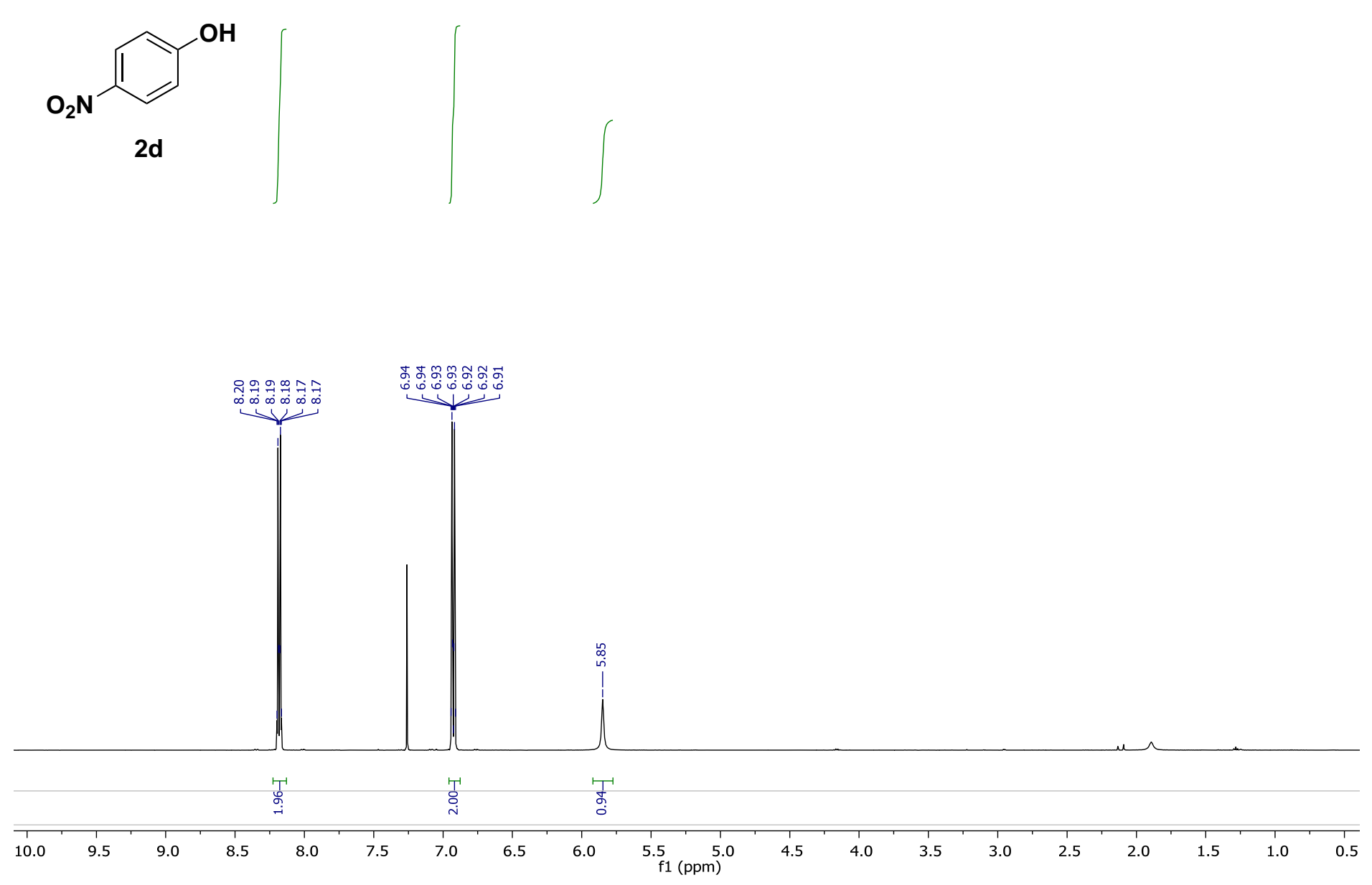

$101 \mathrm{MHz}$, Chloroform-d

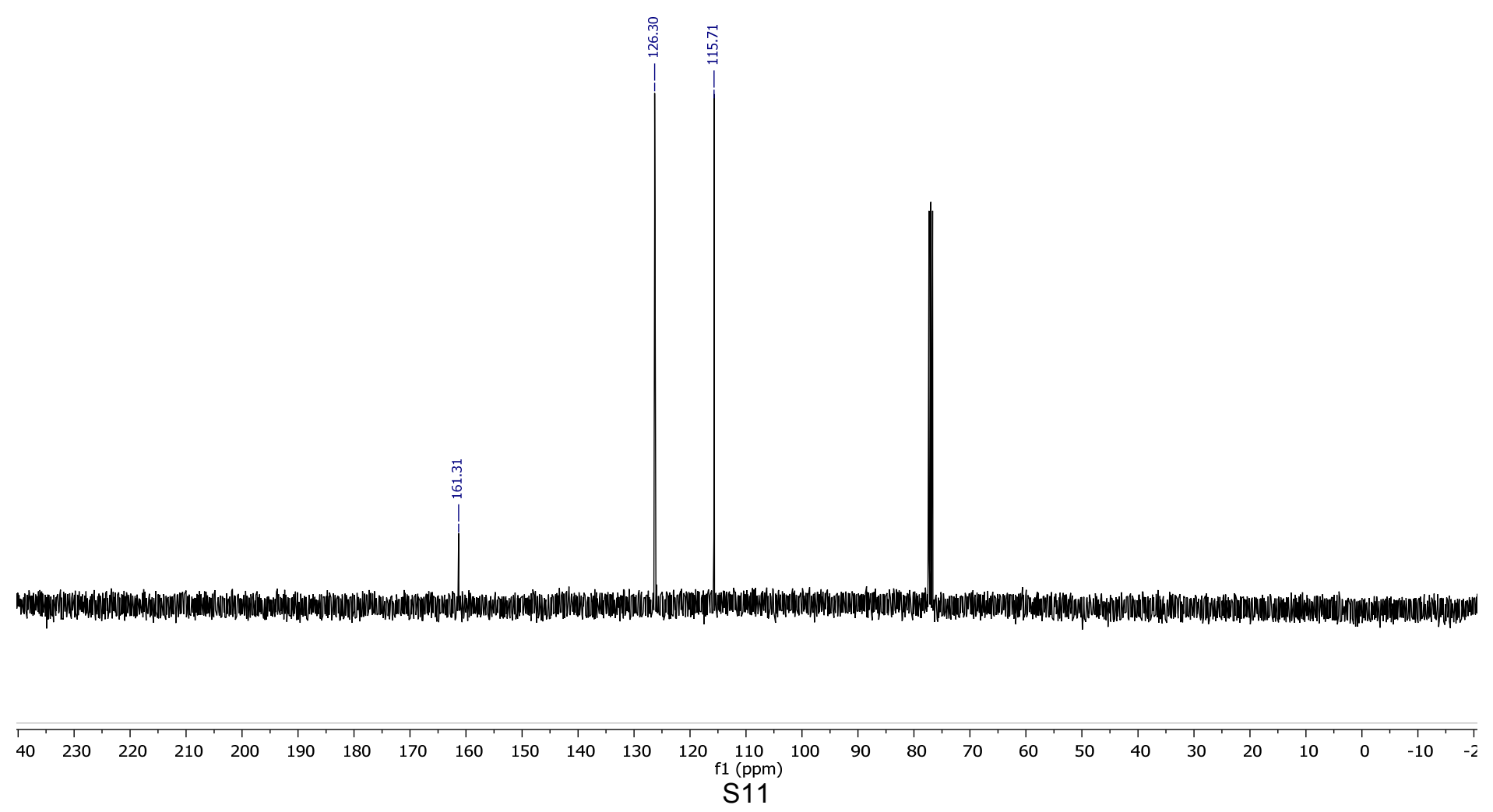


$400 \mathrm{MHz}$, Chloroform-d
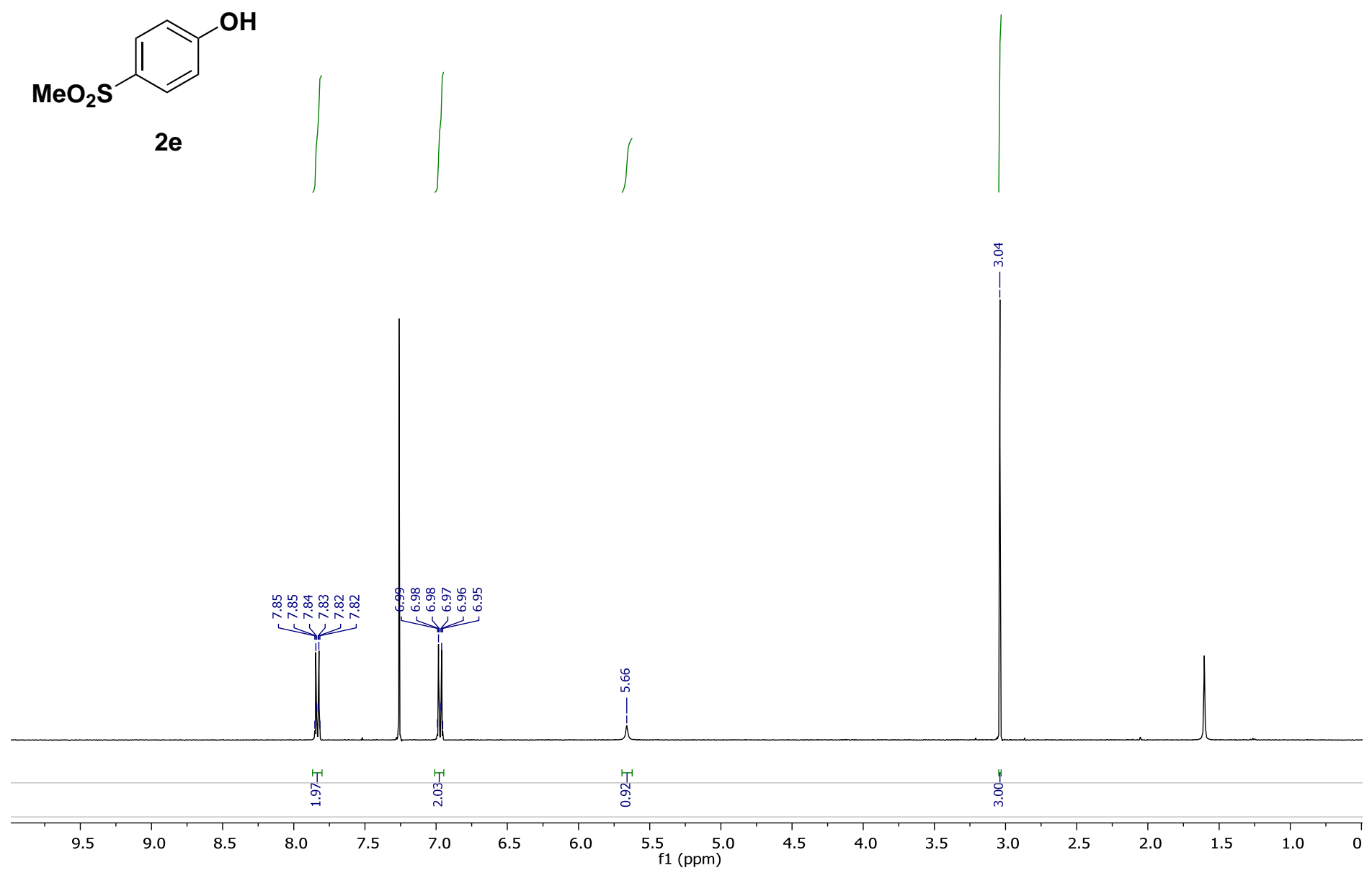

$101 \mathrm{MHz}$, Chloroform-d

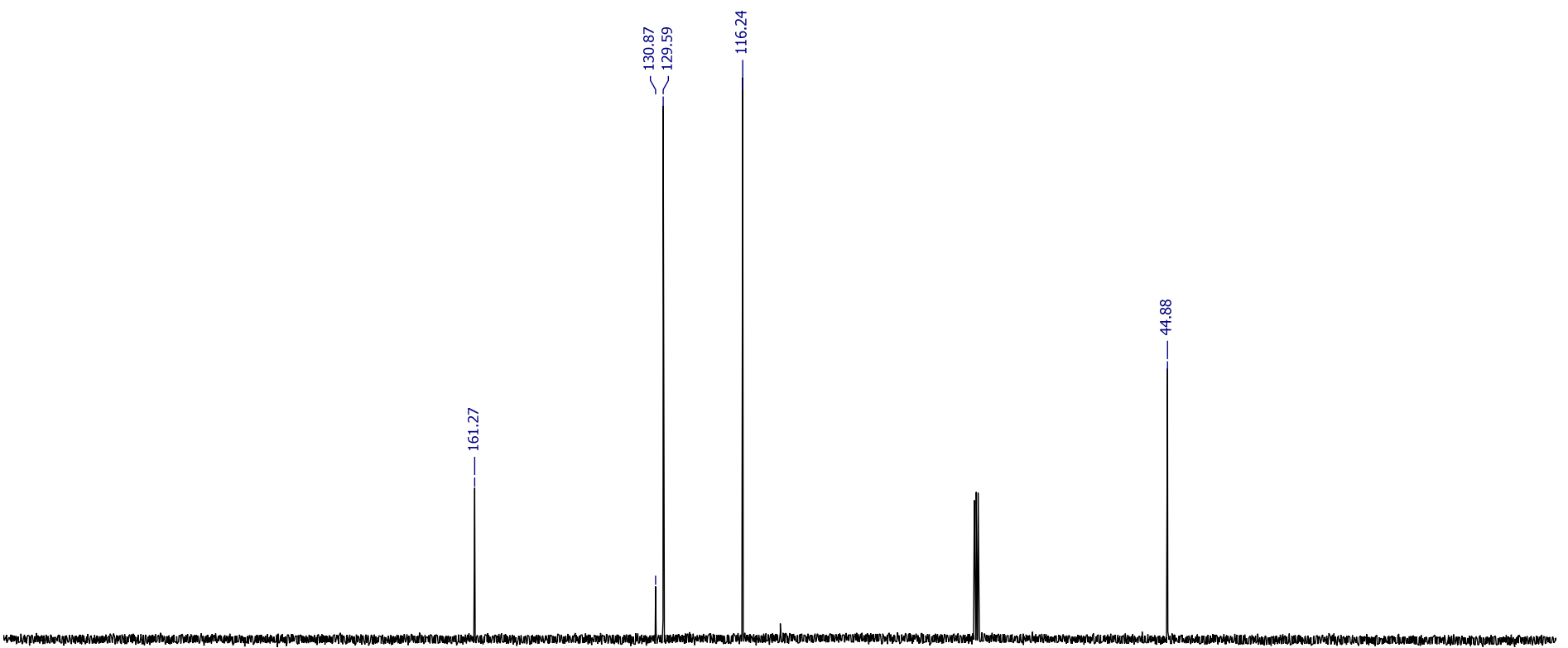

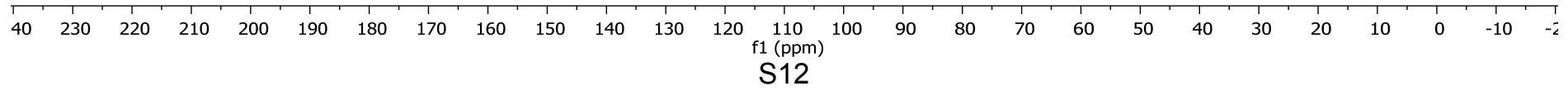


$400 \mathrm{MHz}$, Chloroform-d<smiles>COS(=O)(=O)c1ccccc1O</smiles>

$2 f$
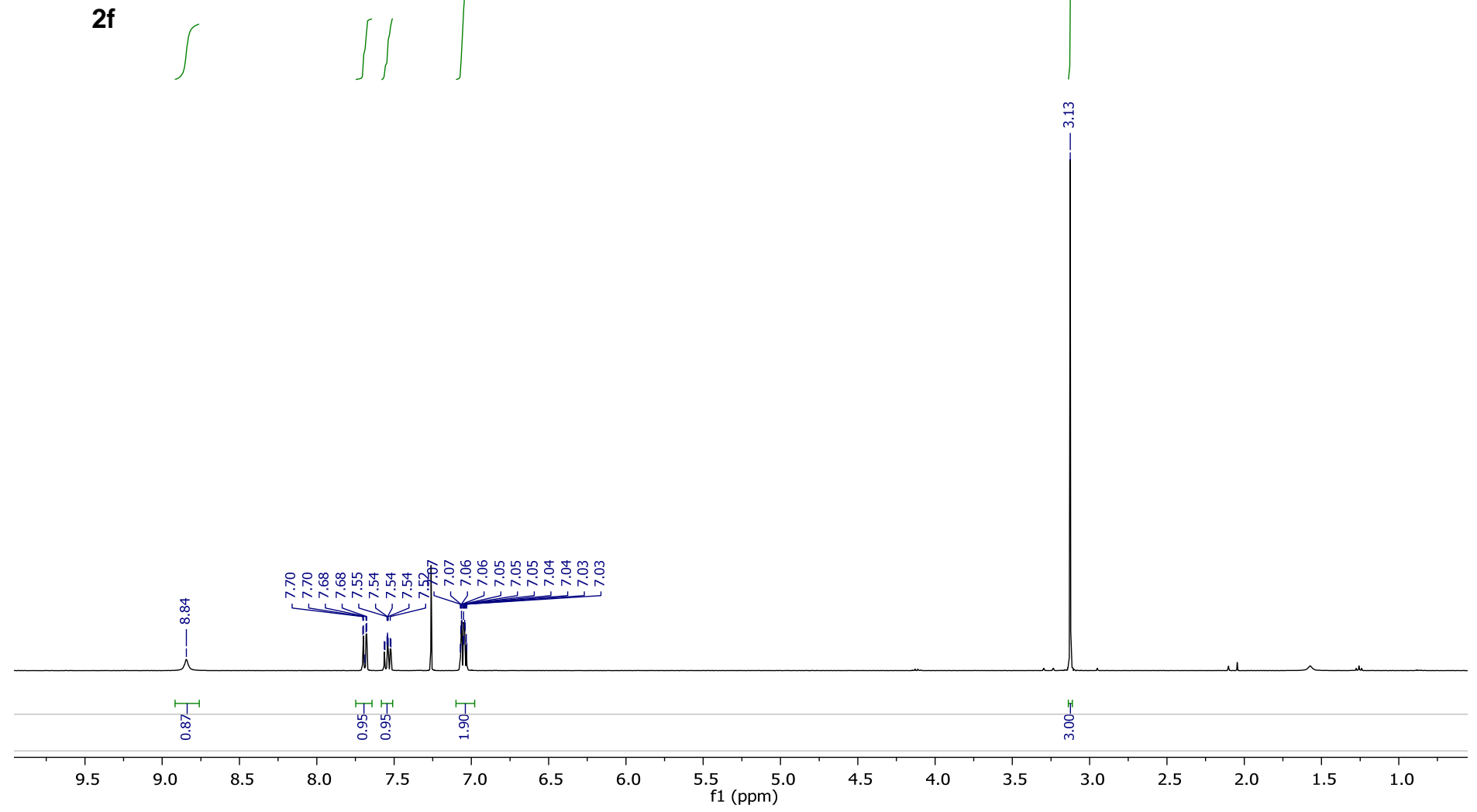

$101 \mathrm{MHz}$, Chloroform-d

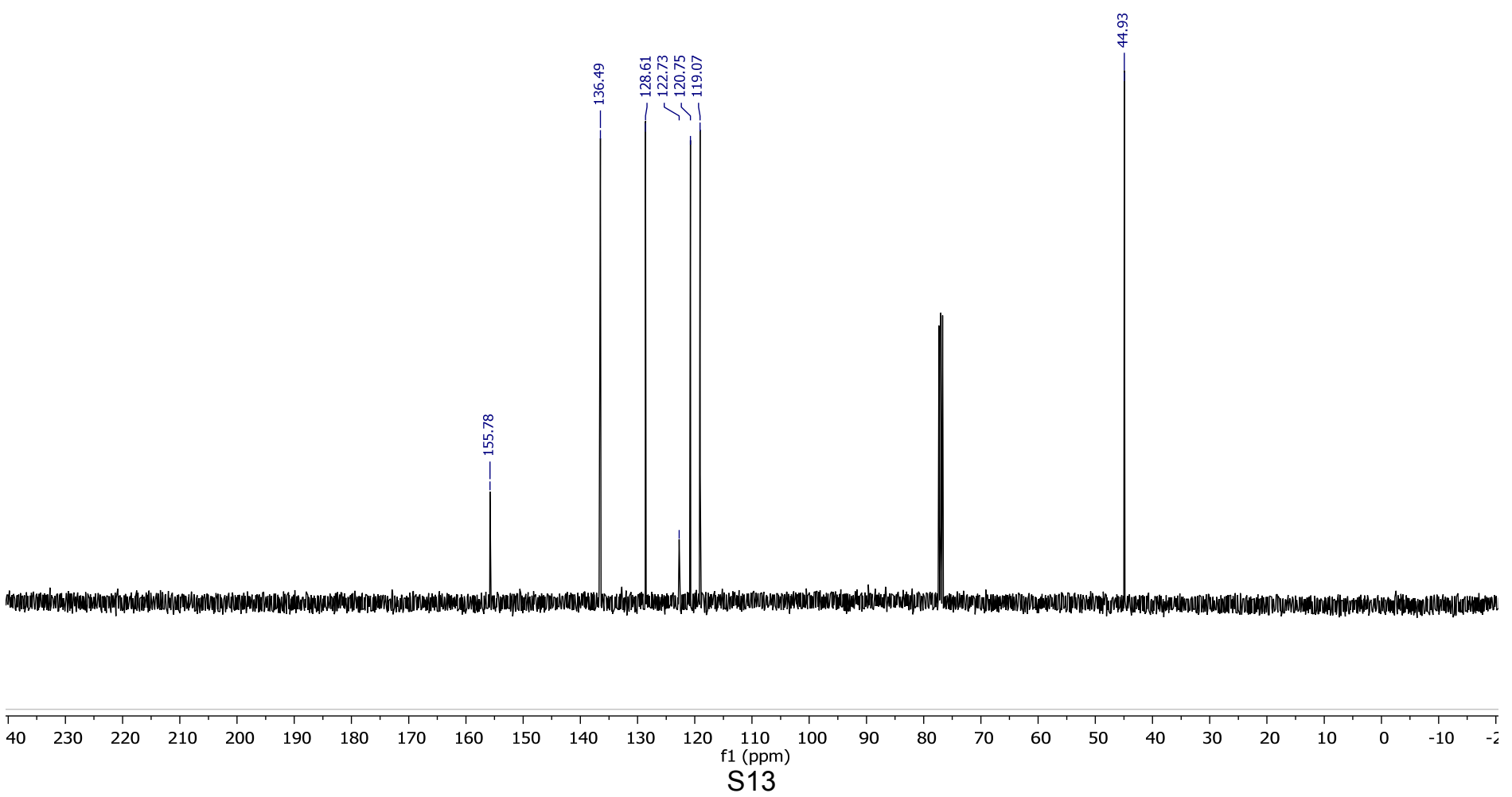


$400 \mathrm{MHz}$, Chloroform-d<smiles>CCNS(=O)(=O)c1ccc(O)cc1</smiles>

\section{$2 g$}
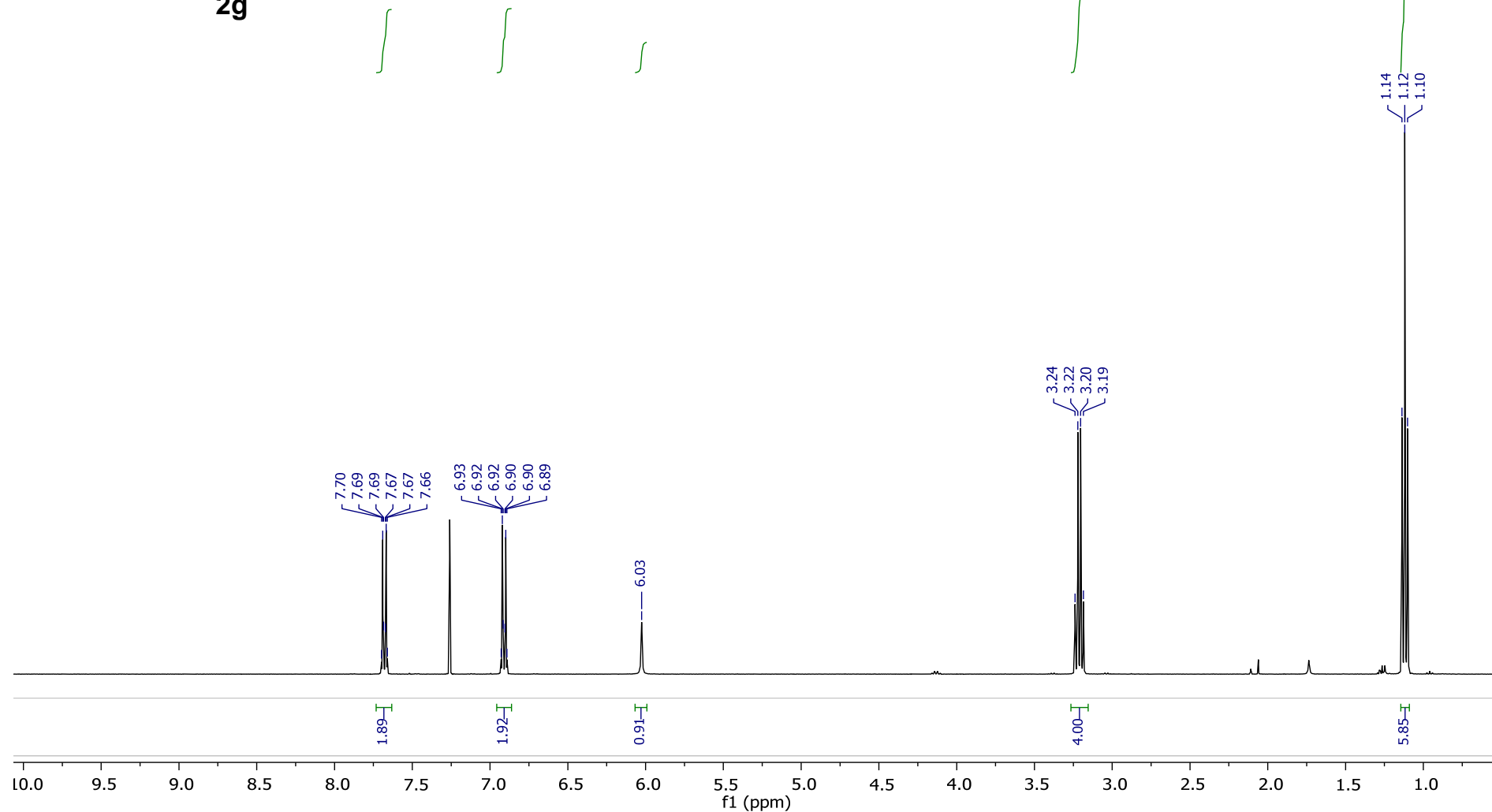

$101 \mathrm{MHz}$, Chloroform-d

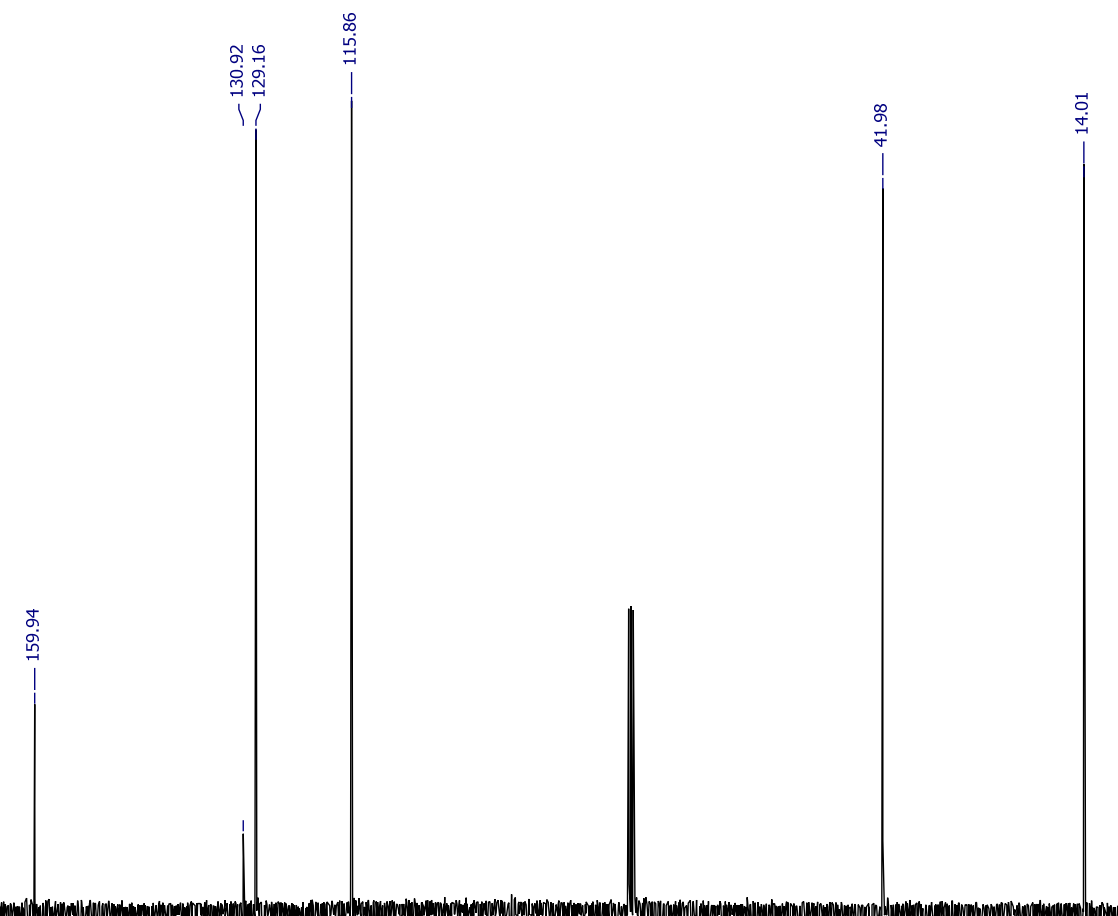


$400 \mathrm{MHz}$, Chloroform-d<smiles>Oc1ccc(C(F)(F)F)cc1Br</smiles>

$2 \mathrm{~h}$

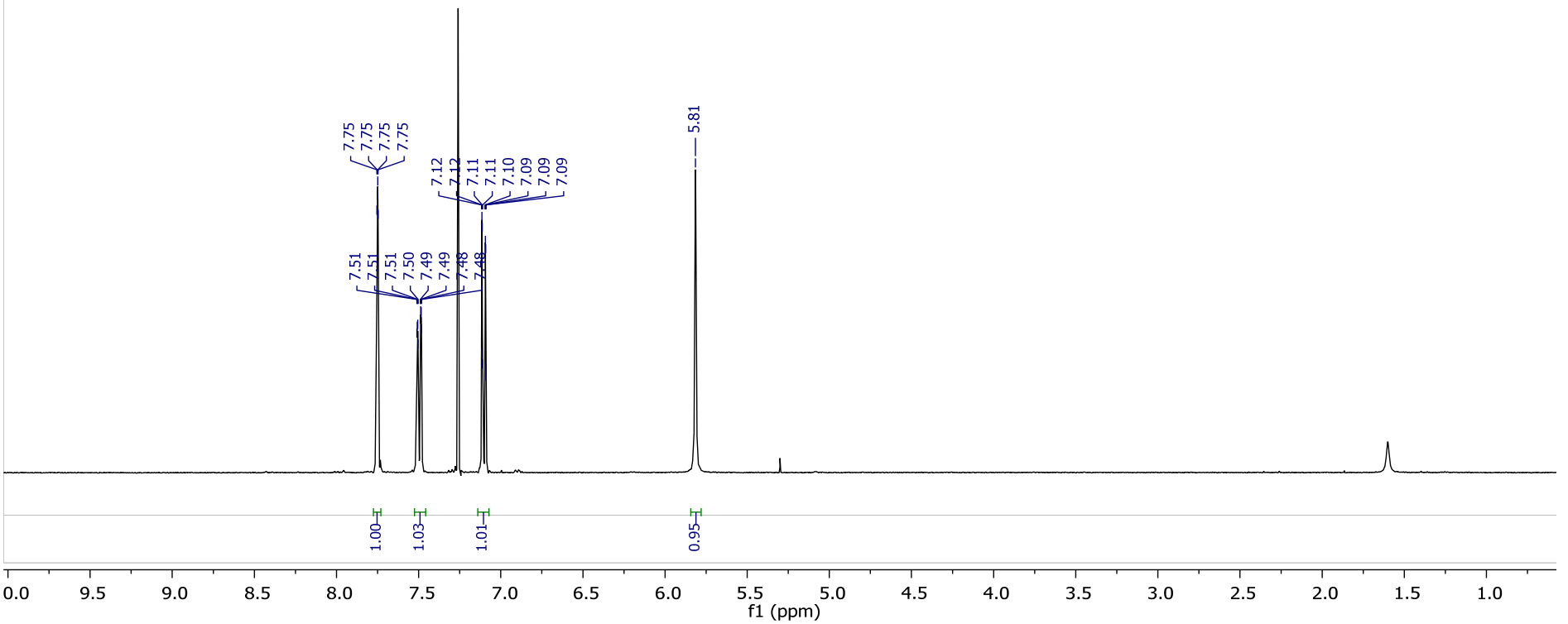

$101 \mathrm{MHz}$, Chloroform-d

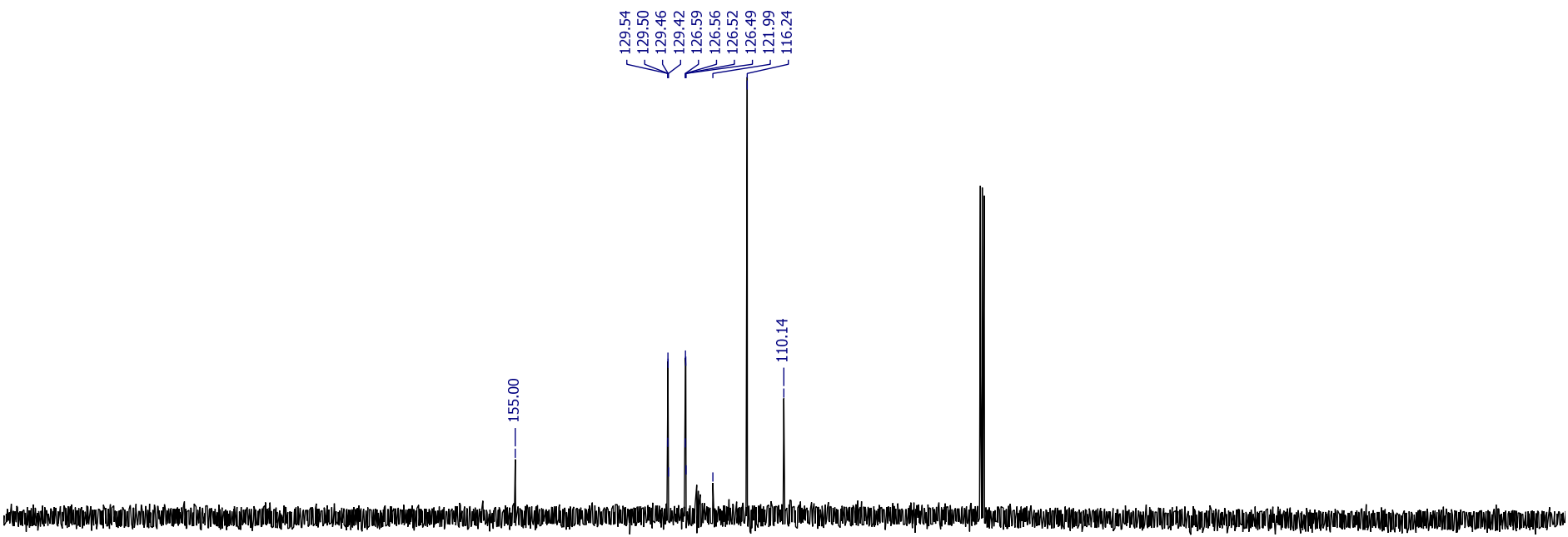



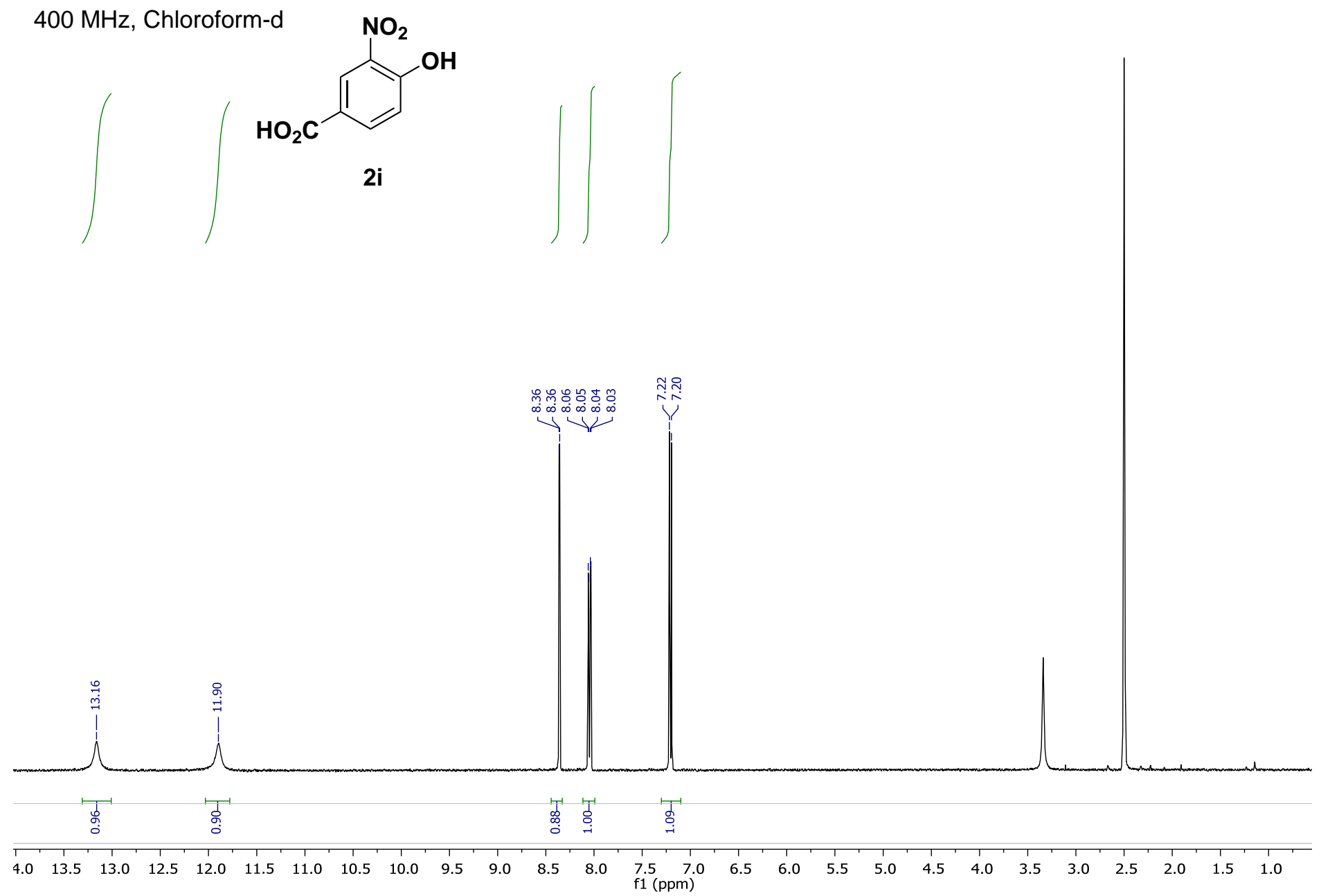

$101 \mathrm{MHz}$, Chloroform-d

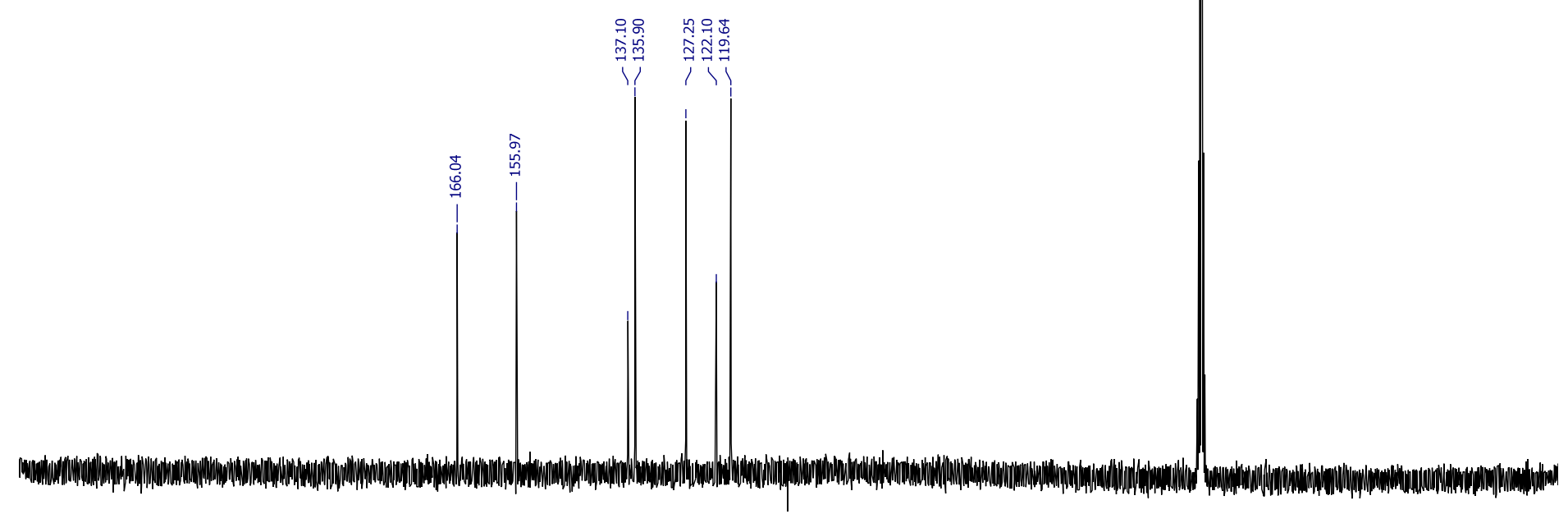

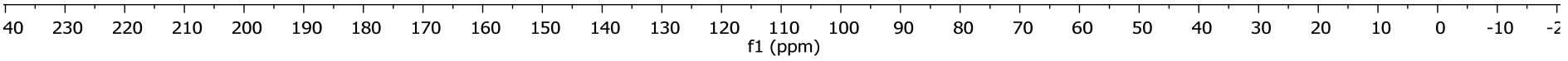
$\mathrm{S} 16$ 
$400 \mathrm{MHz}$, DMSO-d6
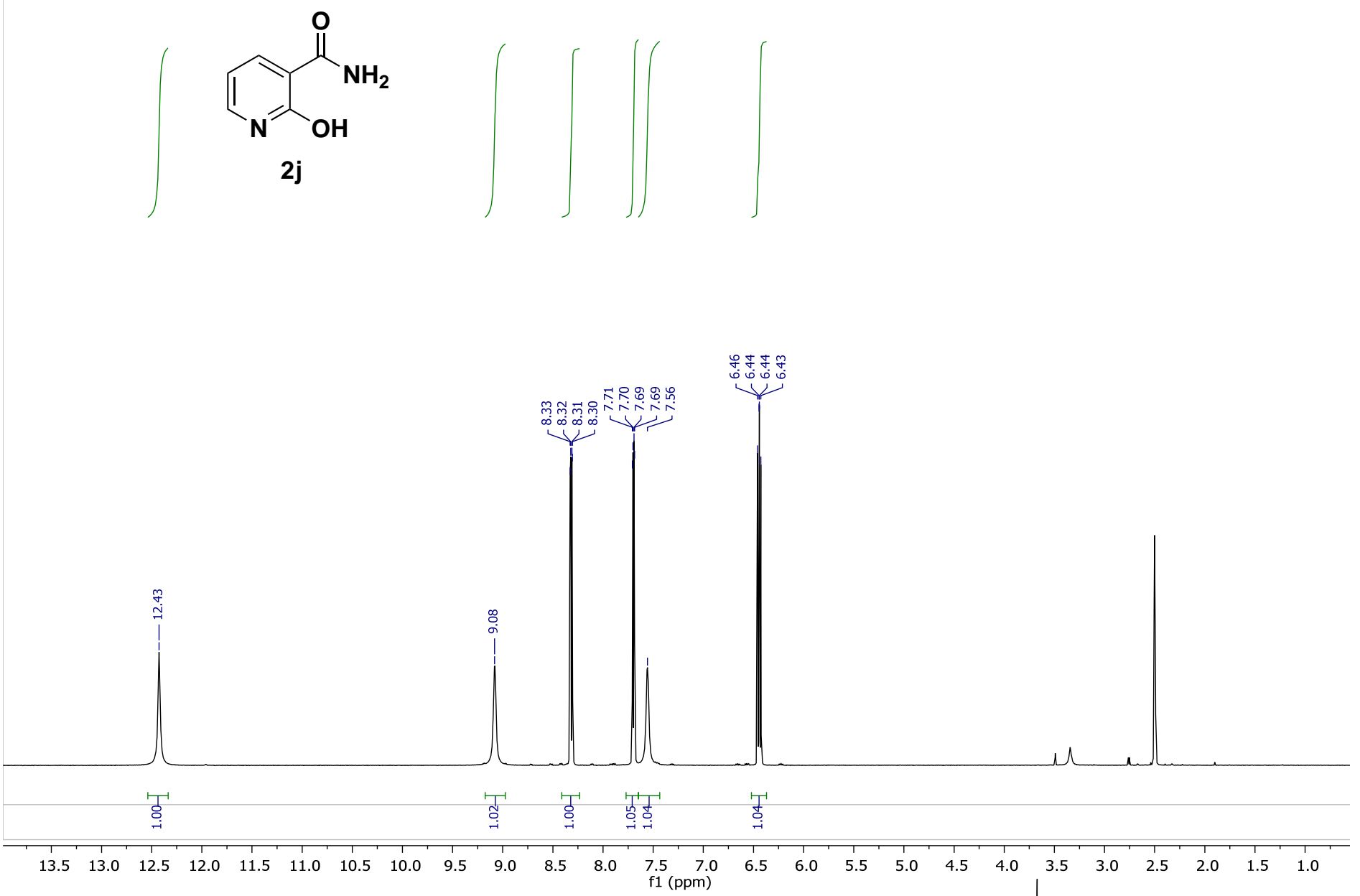

$101 \mathrm{MHz}$, DMSO-d6
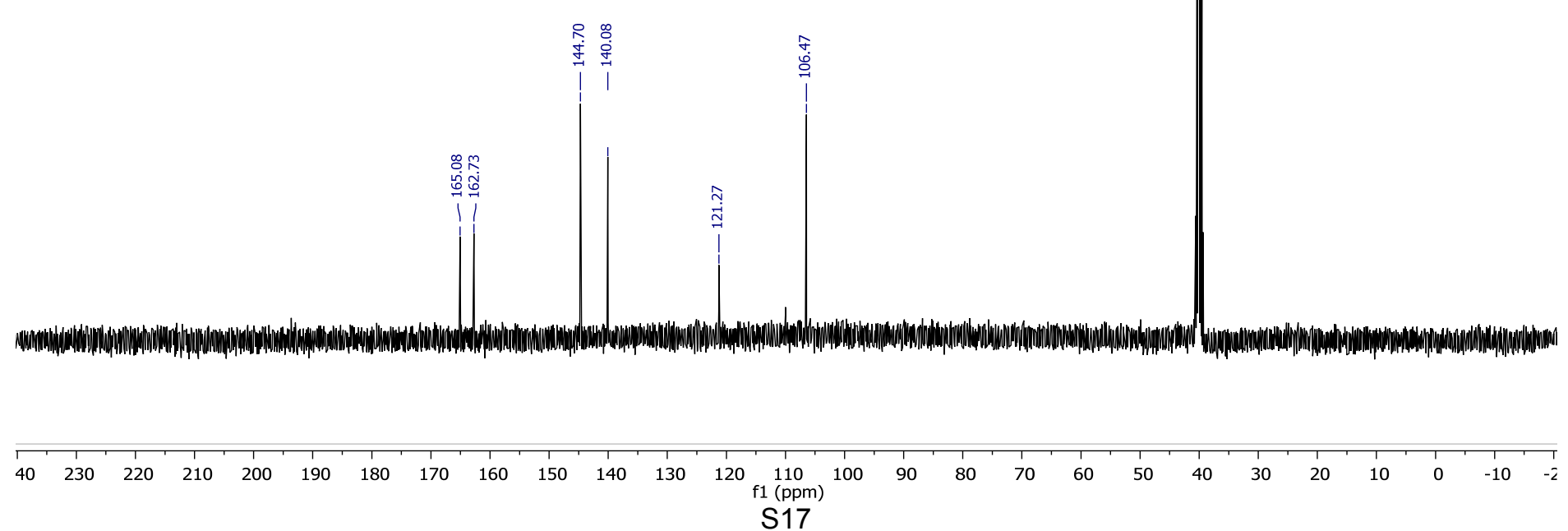
<smiles>Oc1ccc2ccccc2n1</smiles>

$2 \mathrm{k}$
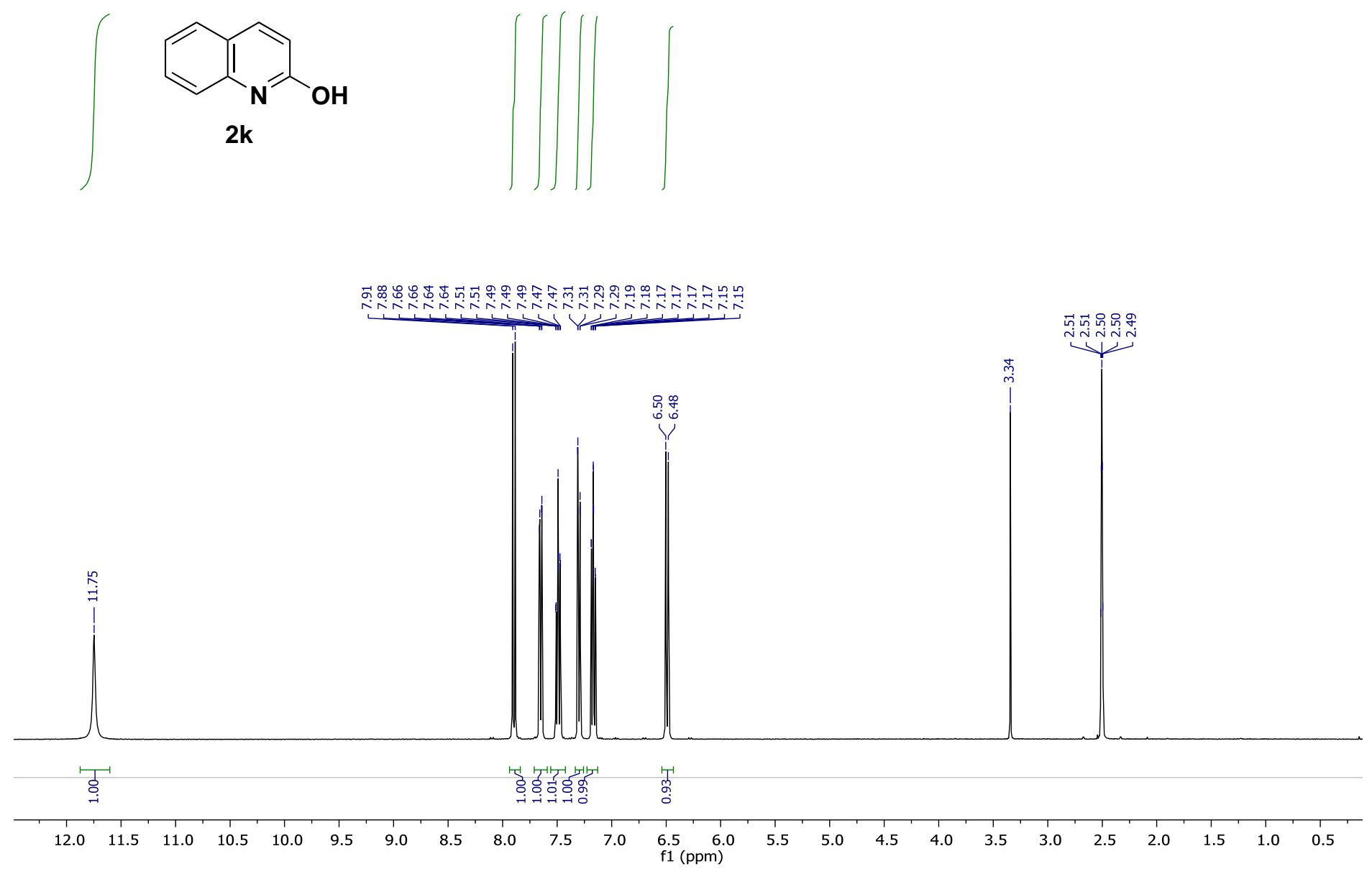

$101 \mathrm{MHz}$, DMSO-d6

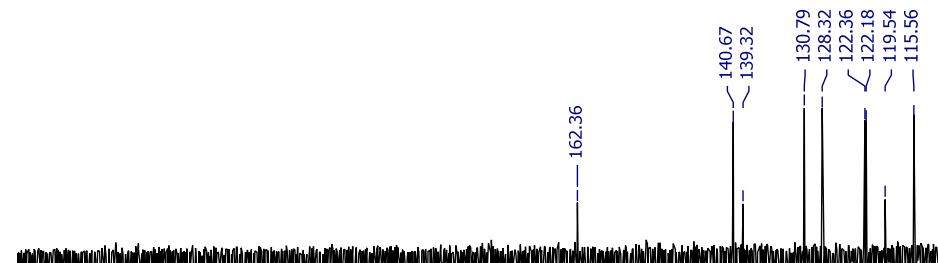


$400 \mathrm{MHz}$, DMSO-d6
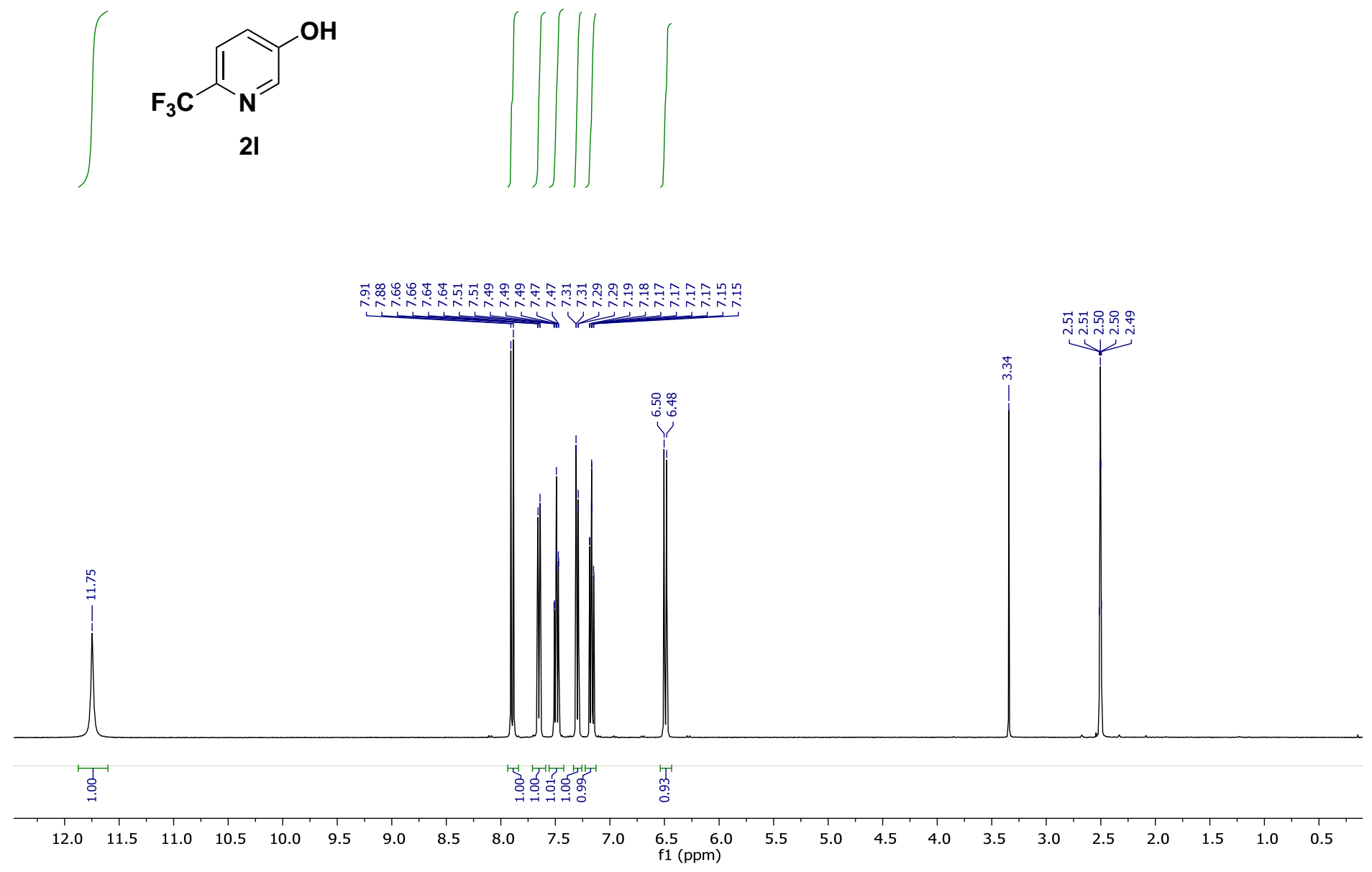

$101 \mathrm{MHz}, \mathrm{DMSO}-\mathrm{d} 6$

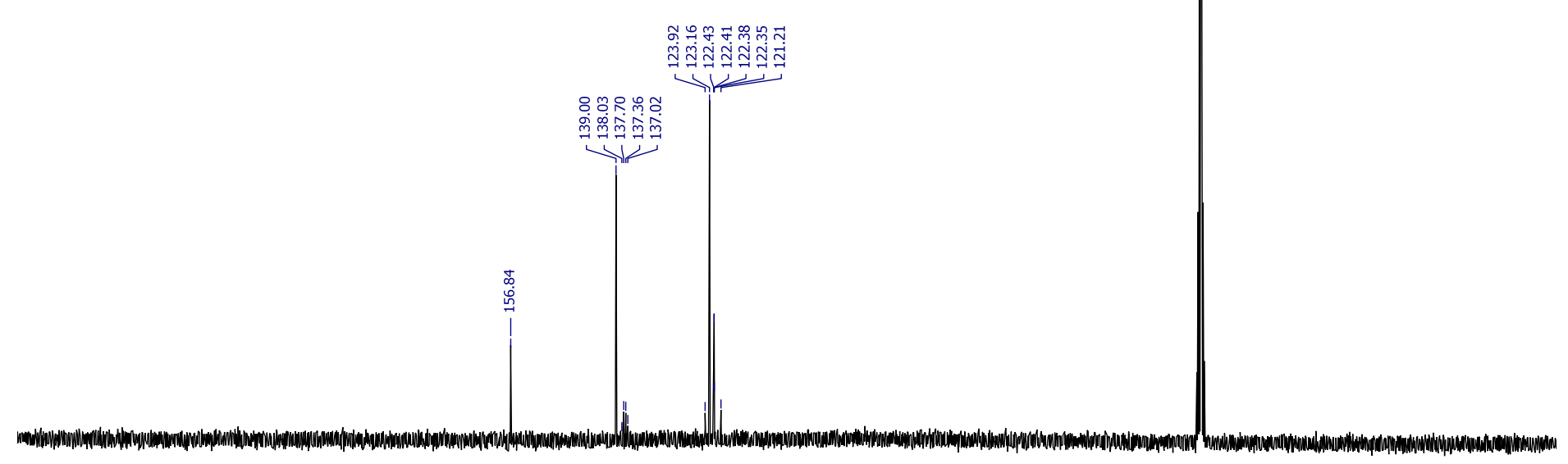

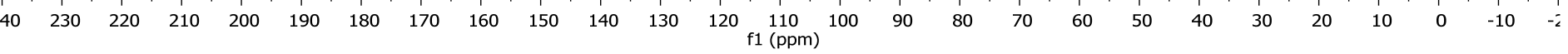


$400 \mathrm{MHz}$, DMSO-d6

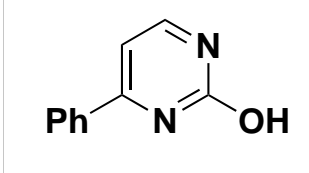

$1 \mathrm{~m}$
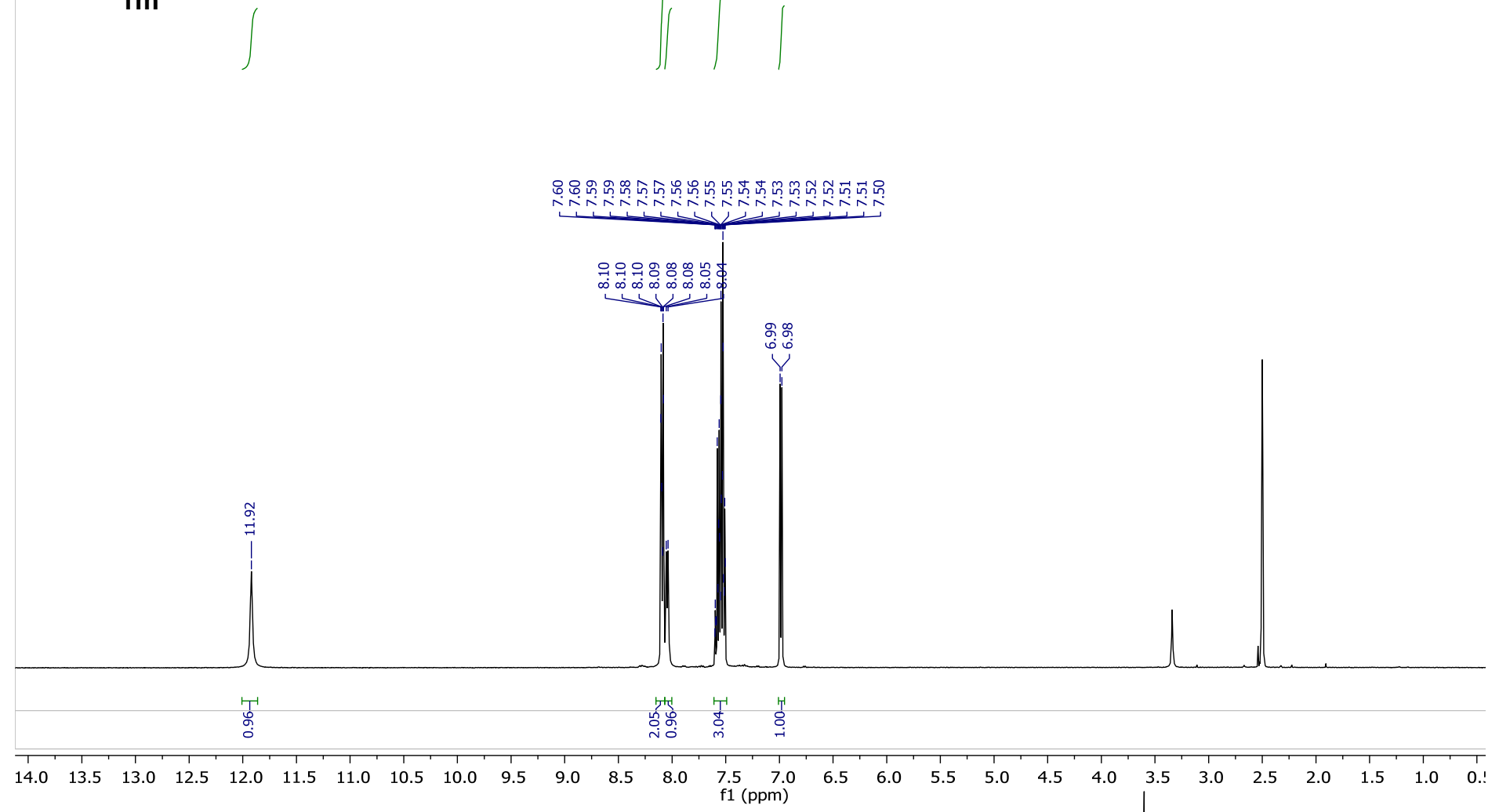

$101 \mathrm{MHz}$, DMSO-d6

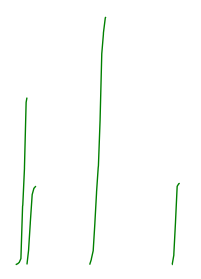

f1 (ppm)

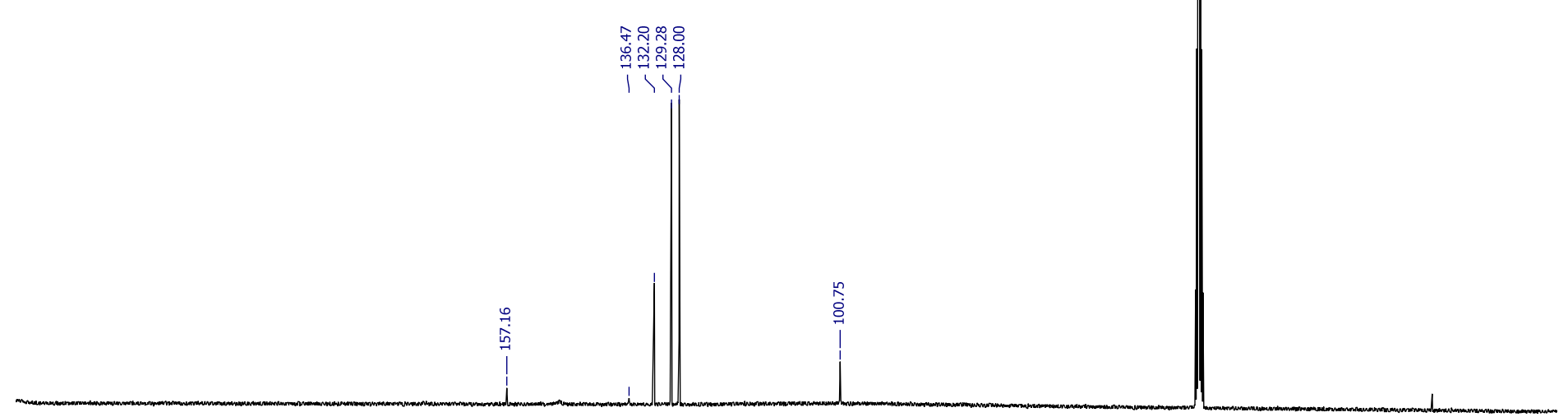

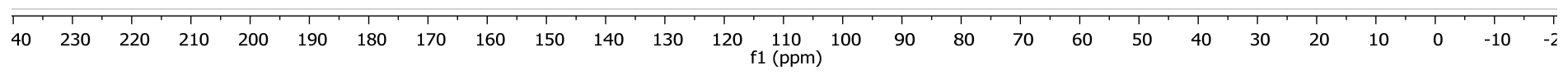


$400 \mathrm{MHz}$, DMSO-d6

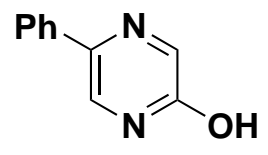

2n
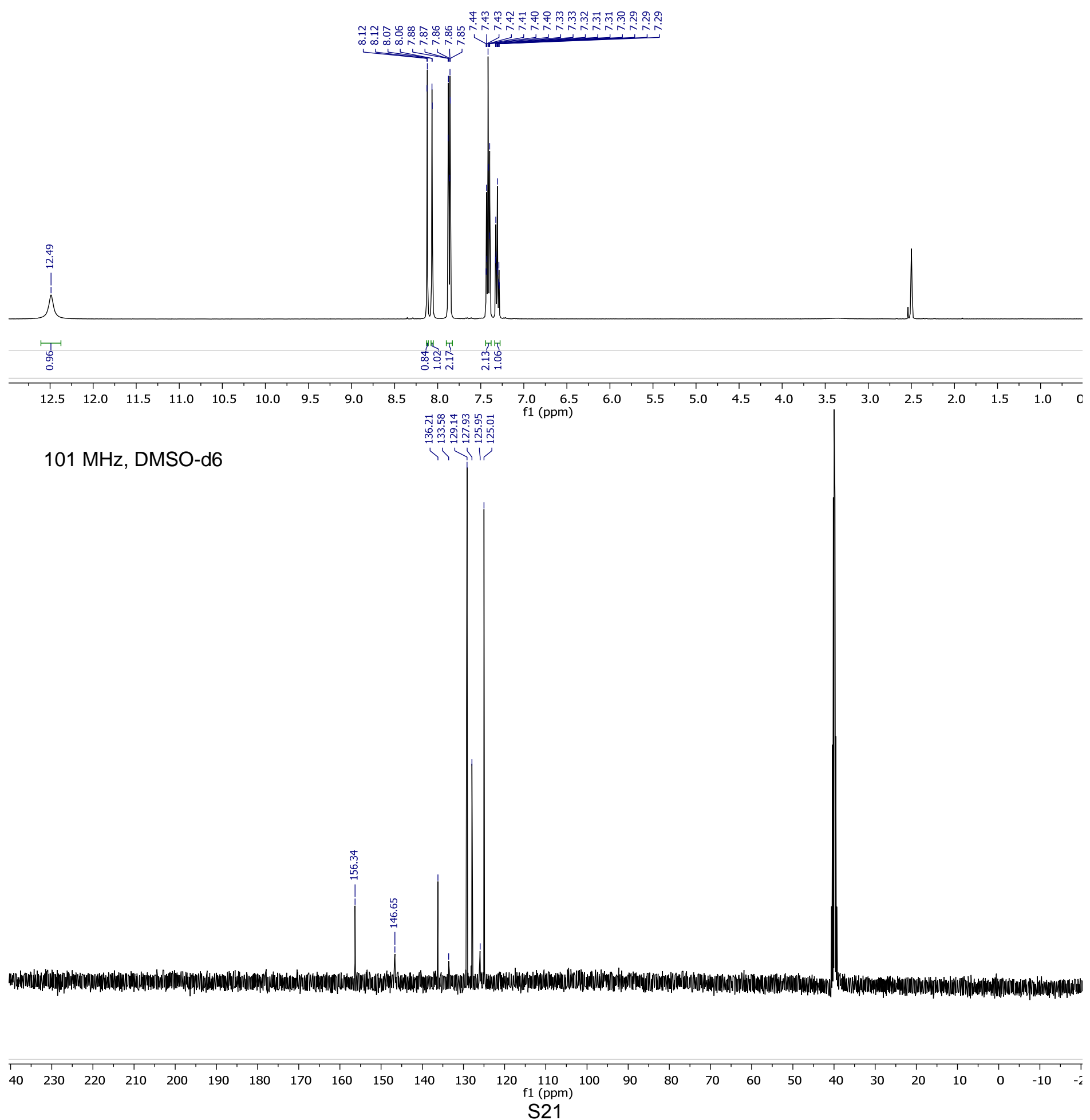
$400 \mathrm{MHz}, \mathrm{DMSO}-\mathrm{d} 6$
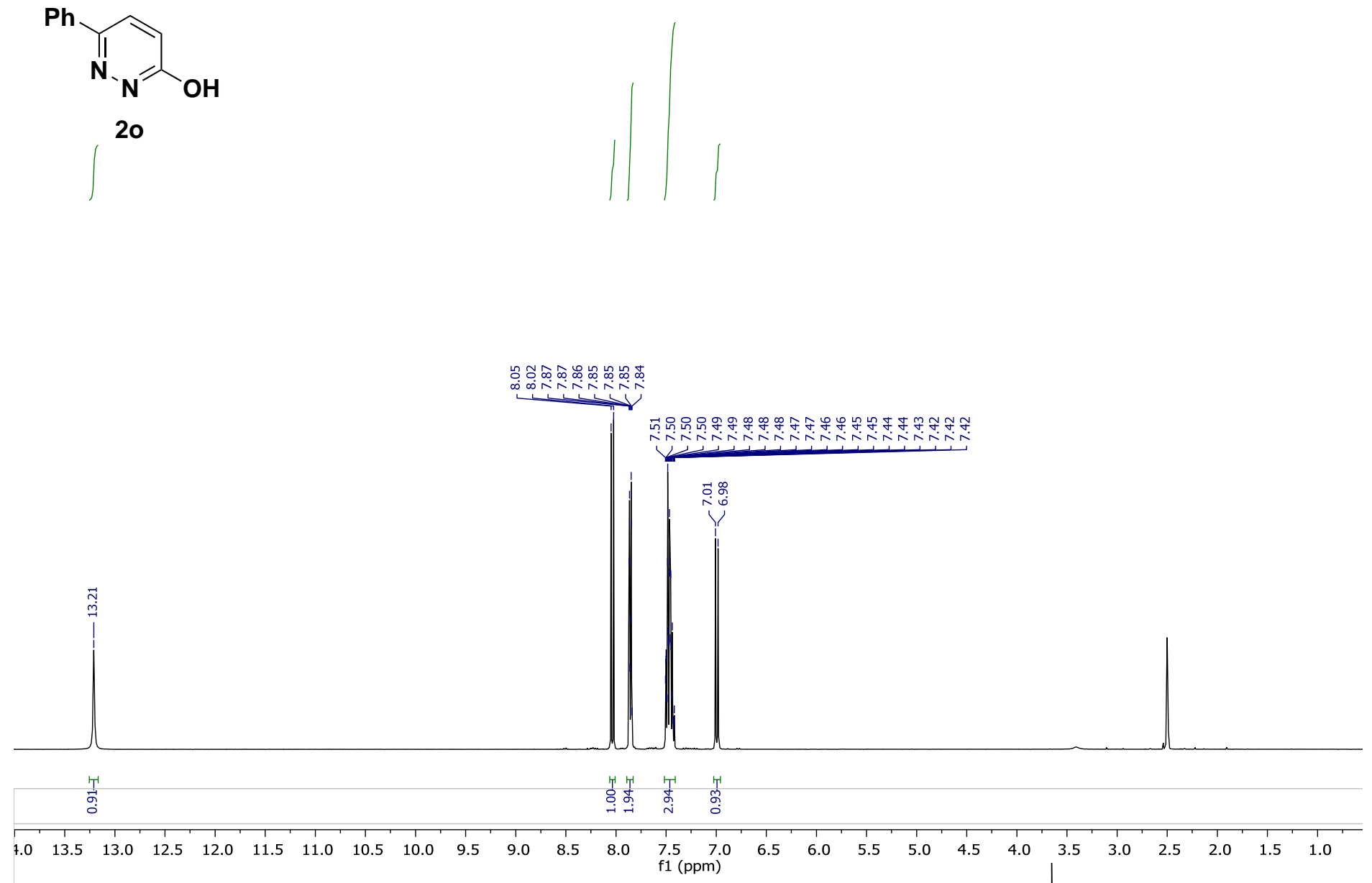

$101 \mathrm{MHz}$, DMSO-d6
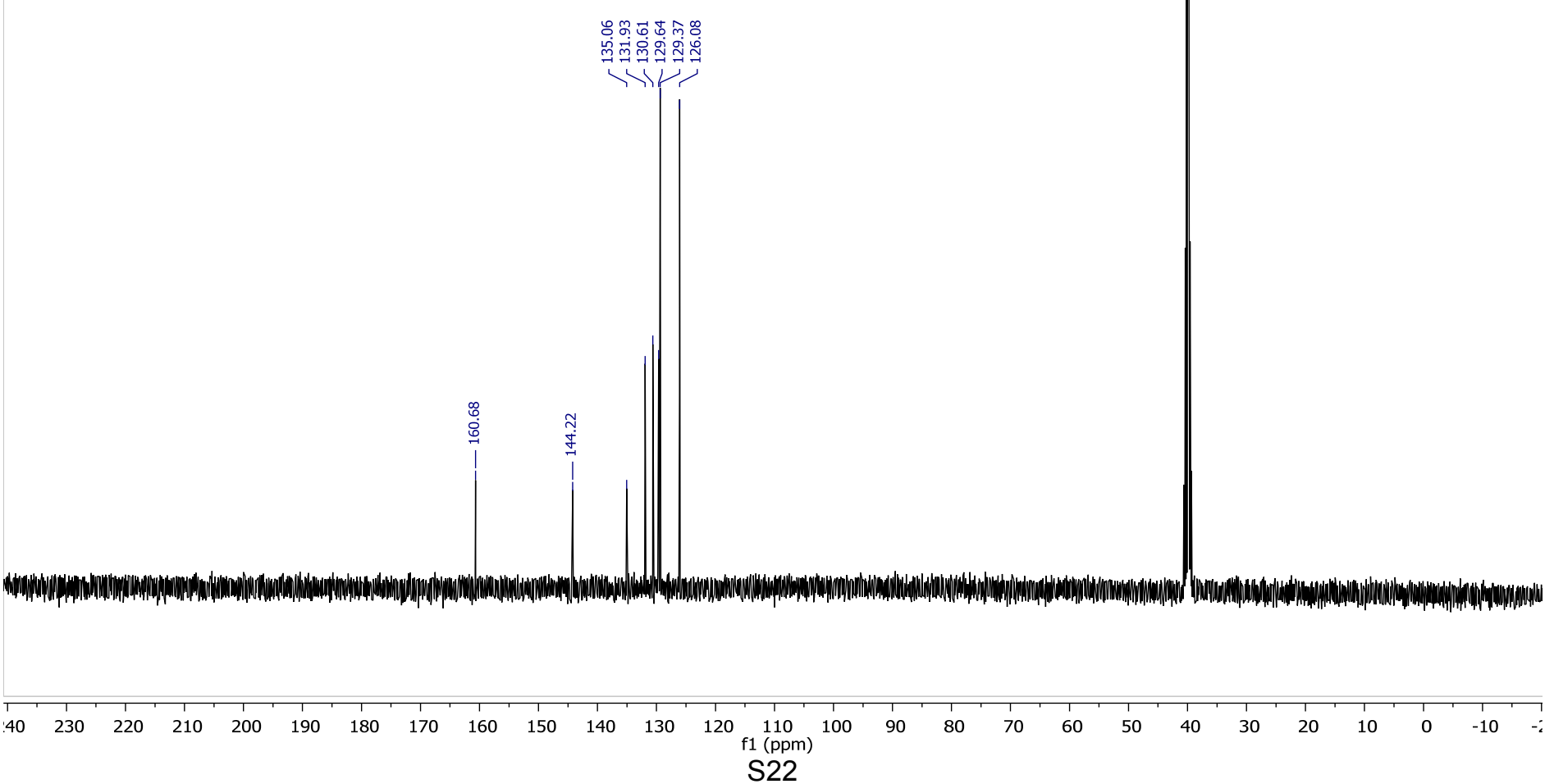


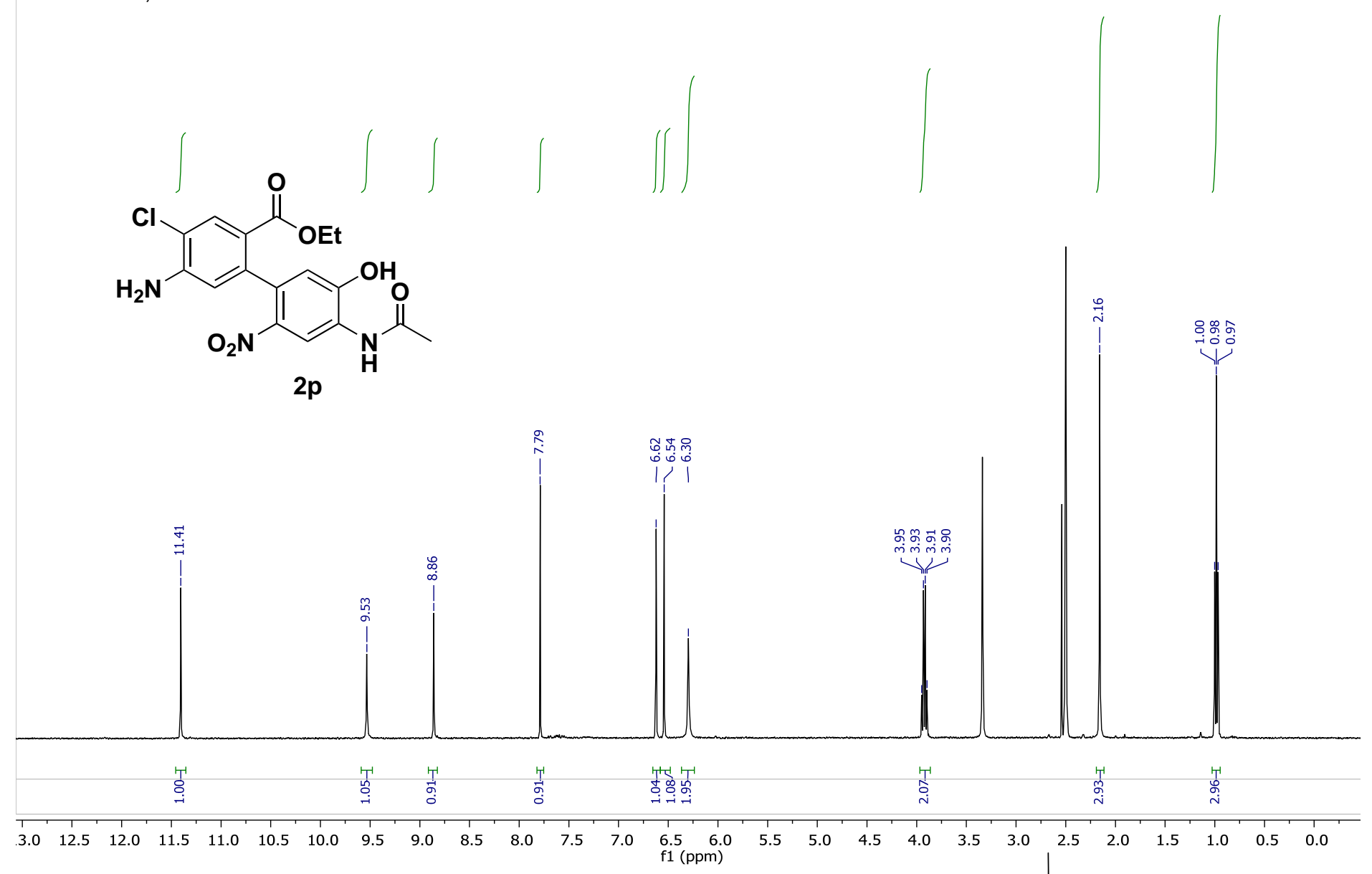

$101 \mathrm{MHz}$, DMSO-d6
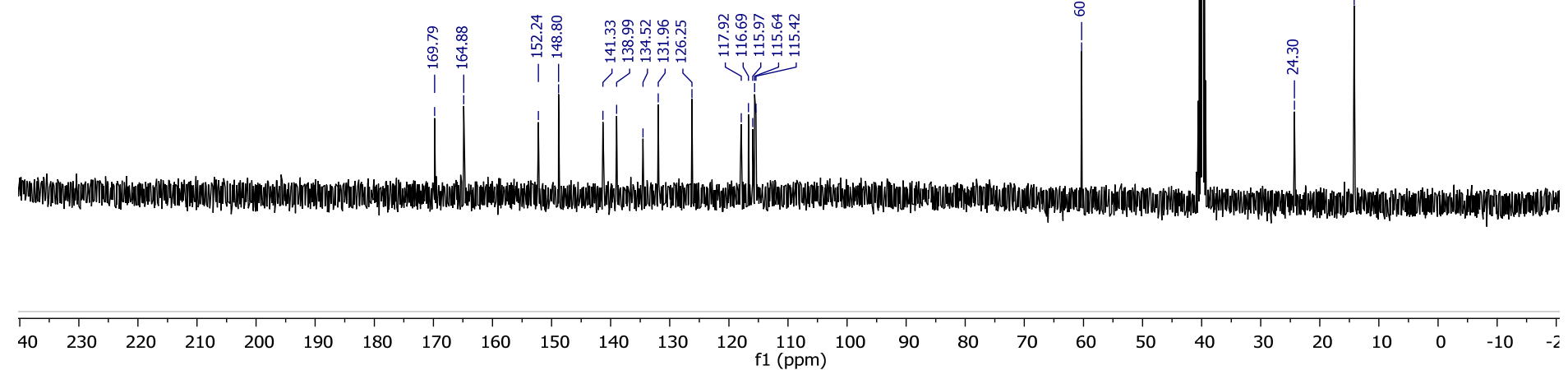
$400 \mathrm{MHz}, \mathrm{DMSO}-\mathrm{d} 6$<smiles>COc1ccc2nc(O)c([OH+]CC3CN(C(C)=O)C(C(C)=O)C3C(C)(C)C)nc2c1</smiles>

$2 q$

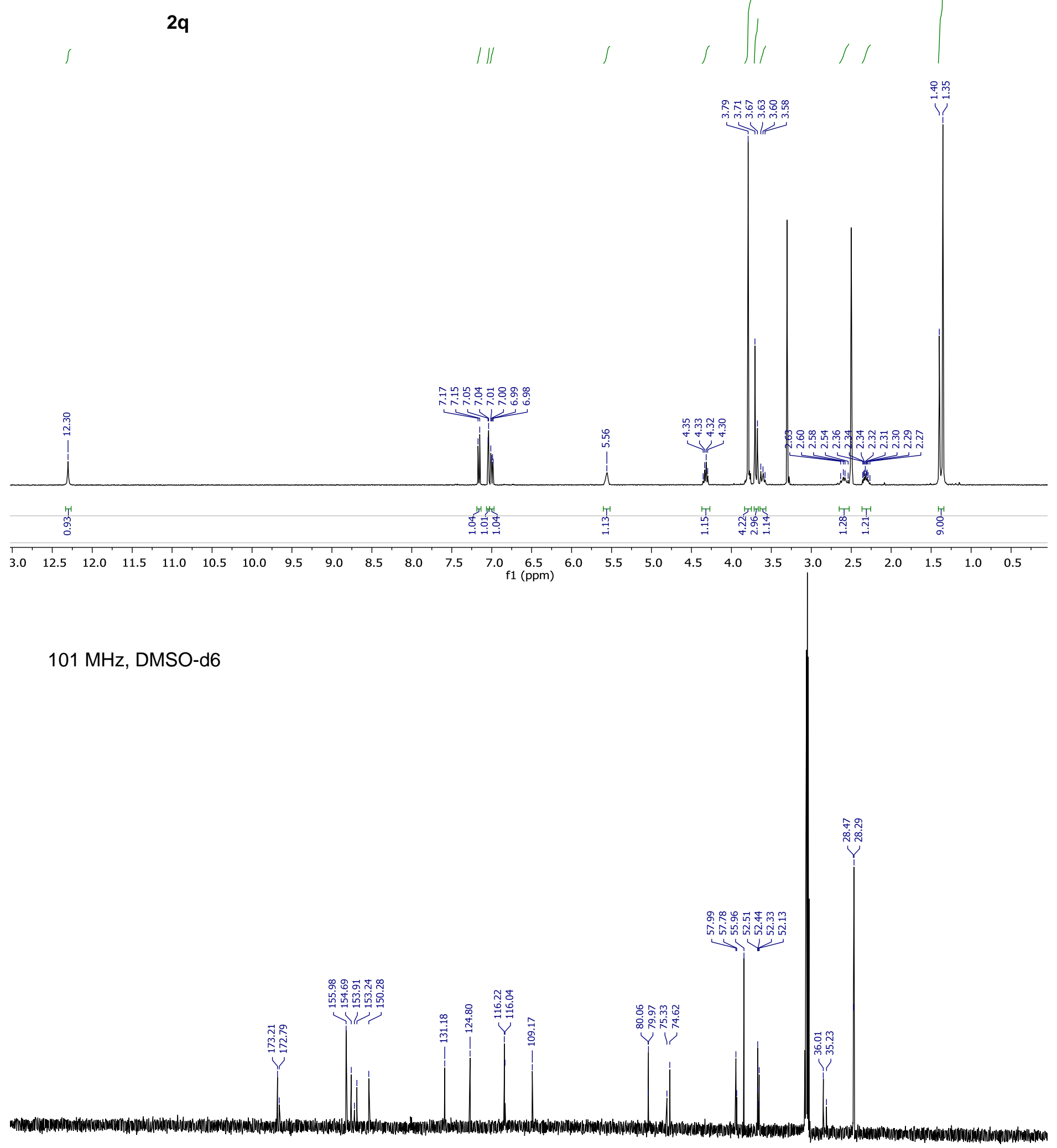

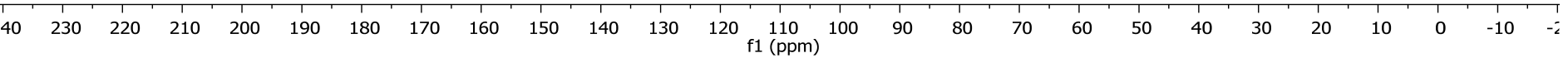

